\title{
Advances in Understanding Mechanisms Underpinning Lithium-Air Batteries
}

\author{
Doron Aurbach ${ }^{1}$, Bryan D. McCloskey², ${ }^{2,3}$ Linda F. Nazar ${ }^{4}$ and Peter G. Bruce ${ }^{5 *}$, \\ ${ }^{1}$ Department of Chemistry, Bar Ilan University, Ramat-Gan 52900, Israel \\ ${ }^{2}$ Department of Chemical and Biomolecular Engineering, University of California, Berkeley, CA, 94720, \\ USA \\ ${ }^{3}$ Energy Storage and Distributed Resources Division, Lawrence Berkeley National Laboratory, Berkeley, \\ CA, 94720, USA \\ ${ }^{4}$ Department of Chemistry, The Waterloo Institute for Nanotechnology, University of Waterloo, \\ Waterloo, Ontario, N2L 3G1, Canada. \\ ${ }^{5}$ Departments of Materials and Chemistry, Parks Road, University of Oxford, Oxford OX1 3PH, UK \\ *e-mail: peter.bruce@materials.ox.ac.uk
}

\begin{abstract}
The rechargeable lithium-air battery has the highest theoretical specific energy of any rechargeable battery and could transform energy storage if a practical device could be realised. At the fundamental level, little was known about the reactions and processes that take place in the battery, representing a significant barrier to progress. Here we review recent advances in understanding the chemistry and electrochemistry that govern the operation of the lithium-air battery, especially the reactions at the cathode. The mechanisms of $\mathrm{O}_{2}$ reduction to $\mathrm{Li}_{2} \mathrm{O}_{2}$ on discharge and the reverse process on charge are discussed in detail, as are their consequences for the rate and capacity of the battery. The various parasitic reactions involving the cathode and electrolyte during discharge and charge are also considered. We also provide views on understanding the stability of the cathode and electrolyte and examine design principles for better lithium-air batteries.
\end{abstract}

\section{Introduction}

Society will need energy storage that exceeds the limits of current technologies if we are to significantly reduce $\mathrm{CO}_{2}$ emissions. The lithium-ion battery is a spectacular success and will continue to improve incrementally for years to come. However, it is imperative that we investigate now alternatives that offer the possibility of going beyond the limits of Li-ion technology, if we are to have any hope of meeting the energy storage needs of future generations ${ }^{1,2,3,4}$.

The Li-air battery, which uses $\mathrm{O}_{2}$ derived from air, has the highest theoretical specific energy (energy per unit mass) of any battery technology, $3500 \mathrm{Wh} / \mathrm{kg}^{5,6}$. Estimates of practical energy storage are uncertain, as many factors are unknown, but values in the range 500 to $1000 \mathrm{Wh} / \mathrm{kg}$ - sufficient to deliver significantly in excess of a $500 \mathrm{~km}$ driving range if employed as an electric vehicle battery -have been proposed, Fig. 1a ${ }^{7}$. The fuel at the positive electrode, $\mathrm{O}_{2}$, is freely available. Operation of the aprotic $\mathrm{Li}^{-} \mathrm{O}_{2}$ battery, which uses a non-aqueous based electrolyte, is illustrated in Fig. 1b. Although Liair batteries have the energy storage advantage over many other rechargeable batteries, understanding of the underpinning chemistry and electrochemistry is lacking. Li-air combines two challenging electrodes, Li metal and $\mathrm{O}_{2}$. Li metal electrodes have been investigated for many years and still do not deliver the necessary cycling efficiency (ratio of discharge/charge capacity) and related suppression of dendrites. ${ }^{8}$ However the prospect of a protected Li anode - in which a solid electrolyte is interposed between the Li metal and the liquid electrolyte - offers an important path of exploration towards a functional high energy Li battery ${ }^{9}$. In contrast, when the aprotic Li-air battery began to be explored there were but a handful of papers on $\mathrm{O}_{2}$ reduction in relevant electrolyte solutions, 
rendering understanding of the $\mathrm{O}_{2} / \mathrm{Li}_{2} \mathrm{O}_{2}$ redox reaction in aprotic solvents a high priority. Aside from the $\mathrm{O}_{2} / \mathrm{Li}_{2} \mathrm{O}_{2}$ redox couple, aprotic $\mathrm{Li}-\mathrm{O}_{2}$ faces a number of other challenges, not least of which is the stability of the electrolyte solution and the cathode towards reduced oxygen species. All of these processes need to be understood and mastered if we are to achieve progress towards a practical battery. Even then the issue of air handling and filtering would need to be addressed by new chemical engineering solutions. Nonetheless, only through a deeper understanding of the science and engineering underpinning the Li-air battery can we hope to make reliable, evidence based predictions of whether it can be a viable technology.

In this Review we focus on the topics that were least understood and on which there has been the greatest progress over the last few years, including the mechanism of $\mathrm{O}_{2}$ reduction to $\mathrm{Li}_{2} \mathrm{O}_{2}$ at the cathode on discharge and the oxidation of $\mathrm{Li}_{2} \mathrm{O}_{2}$ on charge and the mechanisms of electrolyte and cathode degradation. As with all such potentially game changing ideas, they begin with over-hyped expectation, followed by the inevitable disillusionment, thereafter equilibrium is often established; $\mathrm{Li}^{-} \mathrm{O}_{2}$ is now in this third phase ${ }^{10}$. There has been real progress in understanding the fundamental science underpinning Li-air, progress that has explained why many previous results led to the belief that $\mathrm{Li}_{-} \mathrm{O}_{2}$ would inevitably be a low rate, low capacity, high polarization cell, whereas new work on the fundamentals is revealing this is not necessarily the case. No one yet knows if $\mathrm{Li}_{-} \mathrm{O}_{2}$ will ever be a technology, but we owe it to society and our future to explore what might be possible.

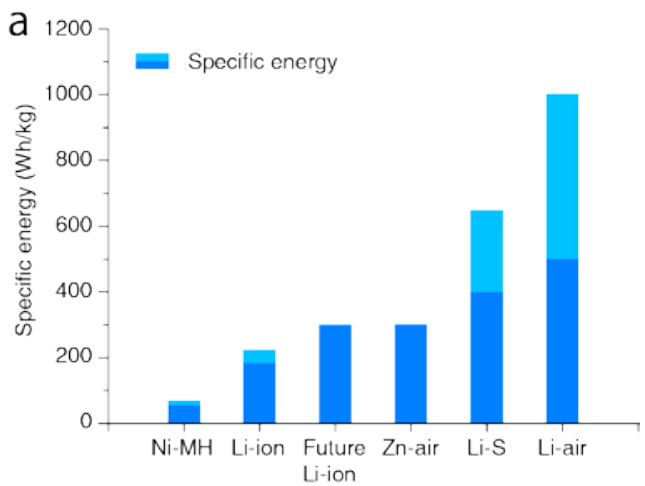

b

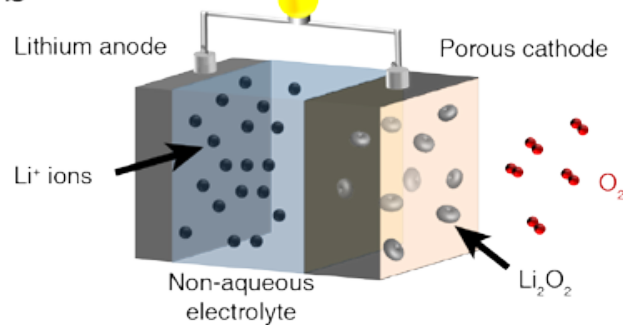

Anode: $\mathrm{Li} \rightleftharpoons \mathrm{Li}^{+}+\mathrm{e} \quad$ Cathode: $2 \mathrm{Li}^{+}+2 \mathrm{e}^{-}+\mathrm{O}_{2} \rightleftharpoons \mathrm{Li}_{2} \mathrm{O}_{2}$

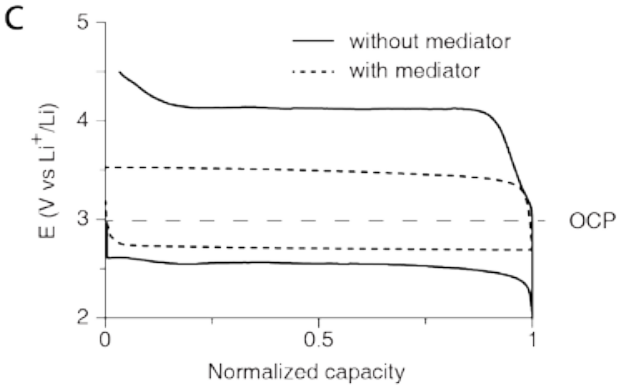

Figure 1 | The basics of lithium-air battery. (a) Practical specific energies for some rechargeable batteries. These are reduced from the theoretical values by e.g. current collectors, cell packaging and system overheads. Light blue indicates range of specific energies; (b) schematic of an aprotic $\mathrm{Li}_{-} \mathrm{O}_{2}$ cell and (c) schematic of a typical load curve for discharge and charge of a $\mathrm{Li}-\mathrm{O}_{2}$ cell without (solid line) and with (short-dash line) redox mediators (molecules that shuttle electrons between the electrode surface and $\mathrm{O}_{2} / \mathrm{Li}_{2} \mathrm{O}_{2}$ in solution). $\mathrm{OCP}=$ open circuit potential.

\section{Mechanisms at the Aprotic $\mathrm{O}_{2}$ Electrode}

Unlike $\mathrm{O}_{2}$ reduction in fuel cells, which produces $\mathrm{H}_{2} \mathrm{O}$, the product at the positive electrode in the $\mathrm{Li}$ $\mathrm{O}_{2}$ cell is the insulating solid $\mathrm{Li}_{2} \mathrm{O}_{2}$, and this has profound implications for the operation of the cell. 


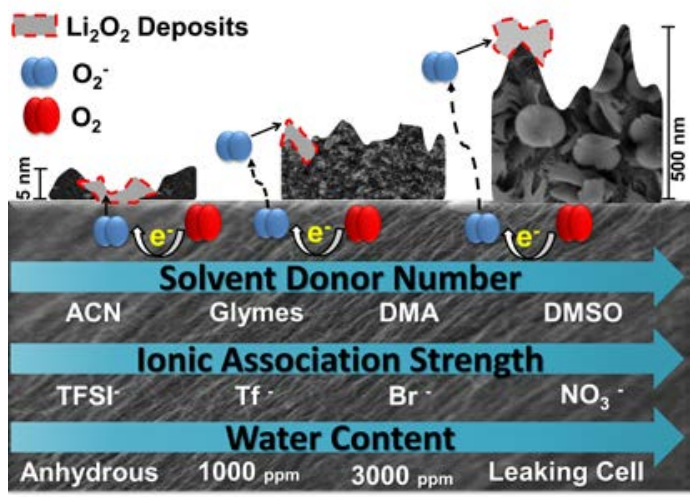

Figure 2 | Surface and solution growth mechanisms of $\mathrm{Li}_{2} \mathrm{O}_{2}$ in different electrolyte solutions. The final step in the formation of $\mathrm{Li}_{2} \mathrm{O}_{2}$ can be either chemical (disproportionation) or electrochemical (second reduction). ACN, Glymes, DMA and DMSO are the solvents acetonitrile, polyethers $\left(\mathrm{CH}_{3} \mathrm{O}\left(\mathrm{CH}_{2} \mathrm{CH}_{2} \mathrm{O}\right)_{n} \mathrm{CH}_{3}\right)$, dimethyl-acetamide and dimethyl sulfoxide. $\mathrm{TFSI}^{-}$and $\mathrm{Tf}^{-}$are the anions bis(trifluoromethane)sulfonimide and trifluoromethanesulfonate. Donor numbers provide a scale for nucleophilicity of solvents, as defined in Ref. 17. The ionic association strength of a salt is determined by the negative charge delocalization, size, and steric effects for a given anion as explained in Ref. 18.
A typical plot of voltage as a function of coulombs passed on the discharge and charge cycle of a $\mathrm{Li}$ $\mathrm{O}_{2}$ cell is shown in Fig. 1c.

The kinetics of the Li anode are relatively facile, so the deviations from the thermodynamic potential (open circuit potential) on discharge and charge (overpotentials) in Fig. $\mathbf{1 c}$ are dictated primarily by reactions at the cathode. The ideal cathode reaction is shown in equ. 1 .

$$
2 \mathrm{Li}^{+}+2 \mathrm{e}^{-}+\mathrm{O}_{2} \underset{\text { charge }}{\stackrel{\text { discharge }}{\rightleftharpoons}} \mathrm{Li}_{2} \mathrm{O}_{2}
$$

Many factors can influence the overpotentials, such as deposition of side-reaction products from electrolyte and electrode degradation. These factors and how they may be mitigated are discussed in subsequent sections. However, the mechanism of the reversible reaction described by equ. 1 lies at the heart of operation of the Li$\mathrm{O}_{2}$ battery and understanding it is key to addressing the technological challenges, hence we begin with this below.

\section{$\underline{\mathrm{O}}_{2}$ reduction to $\mathrm{Li}_{2} \underline{\mathrm{O}}_{2}$ on discharge}

The processes that occur on discharge are highly dependent on competitive factors involving the effective current density /overpotential and whether the $\mathrm{LiO}_{2}$ intermediate is dissolved in solution or adsorbed on the electrode surface ${ }^{11,12,13}$. At high overpotentials/high current densities $\mathrm{O}_{2}$ is reduced to $\mathrm{Li}_{2} \mathrm{O}_{2}$, which grows as a film on the electrode surface. However, batteries must operate at low overpotentials and relatively high currents to maximise energy density (and must be designed to do so). At low overpotentials, $\mathrm{Li}_{2} \mathrm{O}_{2}$ has been observed to grow as surface films or large particles from a solution process, depending on the solvent or salt from which the electrolyte solution is formed or depending on additives in the electrolyte solution (Fig. 2) ${ }^{11,12,13,14,15},{ }^{16}$. Bulk $\mathrm{Li}_{2} \mathrm{O}_{2}$ exhibits ionic conductivity via lithium vacancies, and electronic conductivity via electron holes, both being very low ${ }^{17}$.

At low overpotentials, whether $\mathrm{Li}_{2} \mathrm{O}_{2}$ forms as a film on the electrode or particles from solution is controlled by the solubility of the $\mathrm{LiO}_{2}$ intermediate ${ }^{13}$. The $\mathrm{O}_{2}$ reduction mechanism is summarized in Fig. 3and equs. 2 to 7. The first step is the 1-electron reduction of $\mathrm{O}_{2}$ (dissolved in the electrolyte solution at the electrode surface) to form $\mathrm{LiO}_{2}$. An equilibrium exists between $\mathrm{LiO}_{2}{ }^{*}$ adsorbed on the electrode and $\mathrm{LiO}_{2}$ dissolved in the electrolyte solution, ${ }^{11}$ the position of which is governed by the competition between $\mathrm{LiO}_{2}$ solubility and the adsorption free energy of $\mathrm{LiO}_{2}{ }^{*}$ on the electrode; the former is a significant factor, Fig. $\mathbf{3}^{13,14,16}$. As is generally the case for salts dissolved in aprotic solvents (no hydrogen bonding), the solubility depends primarily on solvation of the cations by the solvent molecules (Gutmann donor number(DN) ${ }^{18}$ and the ionic dissociation strength) ${ }^{19}$ although interactions between the $\mathrm{O}_{2}^{-}$ion and high acceptor number additives were also observed to play a role in $\mathrm{LiO}_{2}$ solubility ${ }^{14,16}$. Where a solvent has a sufficiently high donor number to strongly solvate $\mathrm{Li}^{+}$ 


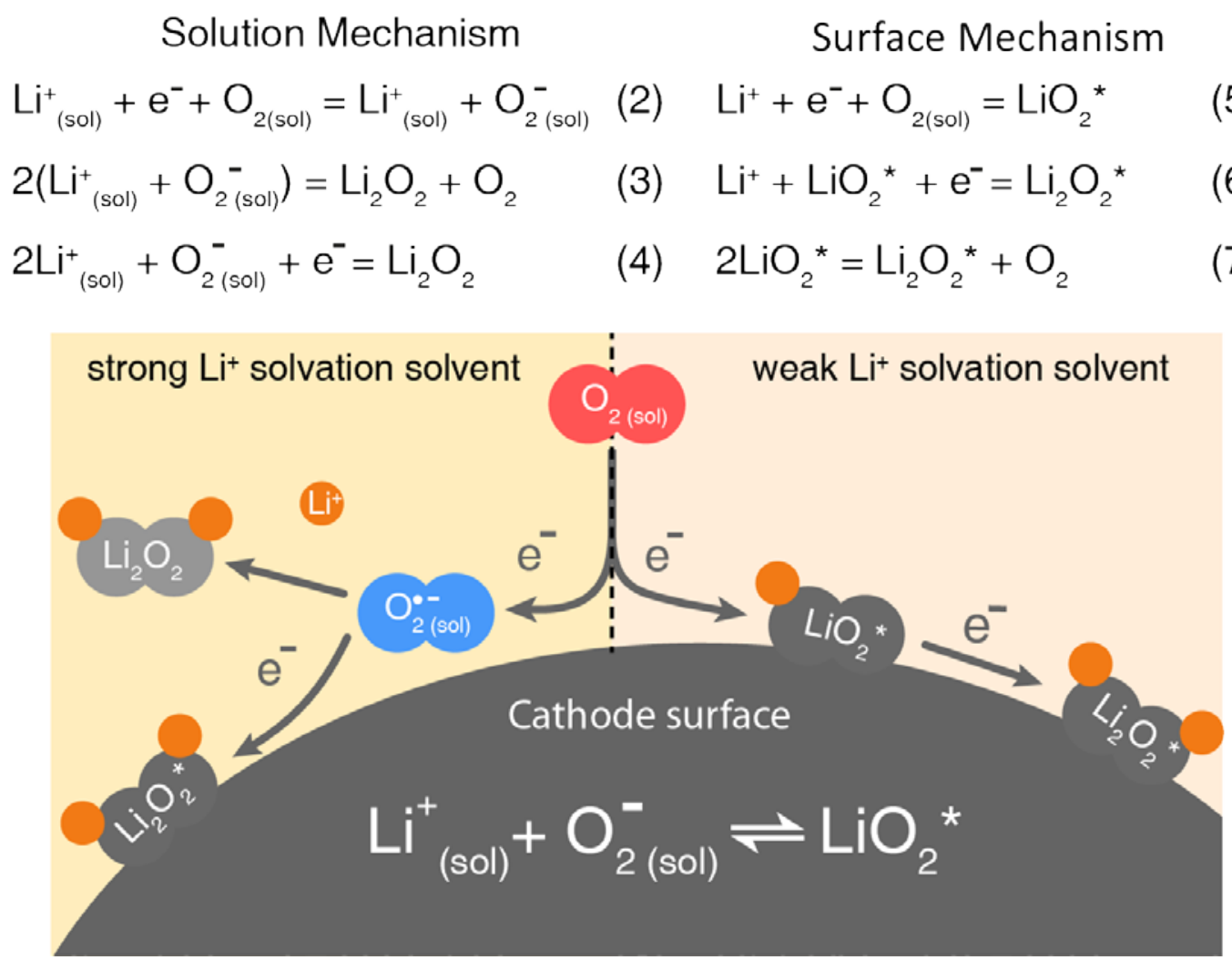

Figure 3 | Reduction mechanisms in a $\mathrm{Li}_{2} \mathrm{O}_{2}$ cell at low overpotentials. Where $\mathrm{LiO}_{2}$ is soluble (e.g. due to use of a high donor number solvent that strongly solvates $\left.\mathrm{Li}^{+}\right) \mathrm{Li}_{2} \mathrm{O}_{2}$ grows as particles from solution. Where $\mathrm{LiO}_{2}$ is insoluble (e.g. due to use of a low donor number solvent that weakly solvates $\mathrm{Li}^{+}$) $\mathrm{Li}_{2} \mathrm{O}_{2}$ grows on the electrode surface. Reactions above refer to those occurring during discharge via the solution mechanism and the surface mechanism.

(e.g. dimethyl sulfoxide, $\mathrm{DMSO}, \mathrm{DN}=30$ ) then $\mathrm{LiO}_{2}$ is dissolved mainly in the electrolyte solution, where it disproportionates to $\mathrm{Li}_{2} \mathrm{O}_{2}$ that grows as micron sized particles, Fig. 3 and equs. 2 and $3^{13,14}$.

If, on the other hand, $\mathrm{Li}^{+}$is weakly solvated (e.g. acetonitrile $\mathrm{CH}_{3} \mathrm{CN}, \mathrm{DN}=14$ ) then $\mathrm{LiO}_{2}$ is present primarily on the electrode surface (equ. 5) where it undergoes a $2^{\text {nd }}$ electron reduction or disproportionation (equs. 6 and 7) to form a $\mathrm{Li}_{2} \mathrm{O}_{2}$ film on the electrode.

It is interesting that the fate of $\mathrm{Li}_{2} \mathrm{O}_{2}$ in aprotic solvents (i.e. without protic additives) depends primarily on the solvation of $\mathrm{Li}^{+}$and not the species actually formed on reduction, $\mathrm{O}_{2}{ }^{-16}$ Superoxide radicals can be stabilized indirectly by the electrolyte counter anions ${ }^{20,21,22}$. In solutions containing highly associated lithium electrolytes, the counter anions are strongly coordinated to the solvated lithium cations. Somewhat analogous to high donor number solvents strongly solvating the $\mathrm{Li}^{+}$ions, this

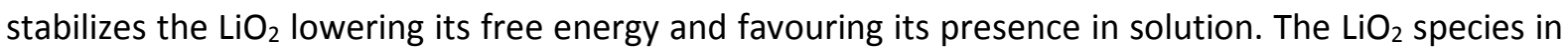
solution can then go on to disproportionate to $\mathrm{Li}_{2} \mathrm{O}_{2}$. Hence, superoxide moieties formed by oxygen reduction can be stabilized even in solvents with low DN number such as glymes. ${ }^{20}$

Additives to the electrolyte solution can also influence the $\mathrm{LiO}_{2}$ solubility, through solvation of $\mathrm{Li}^{+}$or by direct solvation of superoxide using Lewis acidic (electron accepting) electrolyte compositions. For example, when added at impurity ( $<1$ vol\%) levels, water, a strong Lewis acid, along with other protic compounds, can induce solution growth of $\mathrm{Li}_{2} \mathrm{O}_{2}$ through interactions with reduced oxygen species. ${ }^{14,23,24}$ Water unfortunately also induces other parasitic reactions within the cell, such that a search is needed for other, more stable additives that provide a solution pathway to $\mathrm{Li}_{2} \mathrm{O}_{2}$ formation 
and hence increased cell capacity. Additive design criteria to provide both appropriate stability and oxygen species solvation are still not entirely understood.

Understanding the $\mathrm{O}_{2}$ reduction mechanism has important implications for practical $\mathrm{Li}_{-} \mathrm{O}_{2}$ batteries. Much work in the literature has employed ether-based electrolyte solutions. The above mechanistic understanding explains why these low donor number solvents ( $D N \sim 20$ ) result in significant $\mathrm{Li}_{2} \mathrm{O}_{2}$ film growth on the electrode. Such insulating films can grow only to 6-7 $\mathrm{nm}$, resulting in electrode passivation ${ }^{25}$ and leading to low capacities, low rates and early cell death. In contrast, electrolyte solutions that dissolve $\mathrm{LiO}_{2}$ minimize surface film growth, resulting in high rates, high capacities and sustained discharge $\mathrm{e}^{11,12,13}$. This changes thinking regarding the design of porous cathodes for $\mathrm{Li}^{\mathrm{i}} \mathrm{O}_{2}$, away from high surface areas and towards electrodes with a high proportion of large pores to store the $\mathrm{Li}_{2} \mathrm{O}_{2}$ particles growing from solution. $\mathrm{Li}^{-} \mathrm{O}_{2}$ cells with such electrodes can deliver relatively high specific energies (gravimetric) and energy densities (volumetric) compared with those that rely on surface films of $\mathrm{Li}_{2} \mathrm{O}_{2}{ }^{13}$.

The $\mathrm{LiO}_{2}$ intermediate is a disadvantage, especially in its solubilized form. It is reactive, especially towards high donor number solvents that might be used to dissolve $\mathrm{LiO}_{2}$, it is reactive towards possible electrode materials, and it pins the discharge potential at a value somewhat lower than the open circuit potential even in the absence of mass transport limitations ${ }^{26}$. Very recently, an approach has been described that persuades reduction of $\mathrm{O}_{2}$ to $\mathrm{Li}_{2} \mathrm{O}_{2}$ along a different pathway, avoiding $\mathrm{LiO}_{2}$ and its disadvantages ${ }^{27}$. A molecule such as 2,5-di-tert-butyl-1,4-benzoquinone(DBBQ) is added to the electrolyte solution. On discharge, it is first reduced to $\mathrm{DBBQ}^{-}$at the cathode, then binds $\mathrm{Li}^{+}$and reduces $\mathrm{O}_{2}$ to $\mathrm{O}_{2}^{-}$, in the process forming the complex $\mathrm{LiDBBQO}_{2}$ in solution, $\mathrm{LiDBBQO}_{2}$ in turn disproportionates to $\mathrm{Li}_{2} \mathrm{O}_{2}$ and reforms DBBQ. The cycle repeats to sustain discharge ${ }^{27}$. By avoiding $\mathrm{LiO}_{2}$, relatively stable electrolyte solutions that do not dissolve $\mathrm{LiO}_{2}$ e.g. LiTFSI in DME, may be used while still forming $\mathrm{Li}_{2} \mathrm{O}_{2}$ in solution, resulting in significantly high discharge rates and high capacities (typically by 80 fold) than is the case in the absence of DBBQ in the same DME electrolyte, Fig. 4. The new intermediate, $\mathrm{LiDBBQO}_{2}$, is more stable (lower free energy) than $\mathrm{LiO}_{2}$ thus lowering the overpotential on discharge, Fig. 1c. Another benefit of avoiding reactive solution-soluble $\mathrm{LiO}_{2}$ is potentially reduced side-reactions, evidenced by higher yields of $\mathrm{Li}_{2} \mathrm{O}_{2}(95 \%$ with $\mathrm{DBBQ}$ in DME compared with $87 \%$ without). This reduction mechanism may be distinguished from previous studies that used molecular shuttles, which reduce $\mathrm{O}_{2}$ by outer-sphere electron transfer at potentials lower 
than direct reduction, e.g. viologen, or by molecules that bind $\mathrm{O}_{2}$ before and after reduction, pthalocyanines. ${ }^{28,29,30}$

Other discharge mechanisms that result in different products have also very recently been reported. Lu et al. suggested that it may be possible to stabilize $\mathrm{LiO}_{2}$, which is known to be stable only at $<50$ $\mathrm{K}^{31,32}$, by adsorption on an iridium-based electrode such that this becomes the product of the reaction rather than an intermediate ${ }^{33}$. Such a cell reportedly shows much better reversibility than the $\mathrm{O}_{2} / \mathrm{Li}_{2} \mathrm{O}_{2}$ reaction. It should be noted that work continues on the aqueous $\mathrm{Li}^{-} \mathrm{O}_{2}$ battery and its related $\mathrm{Zn}-\mathrm{O}_{2}$ cousin $^{34,35}$. The fascinating prospect of a $\mathrm{Li}^{-} \mathrm{O}_{2}$ aprotic battery in which the reaction at the cathode involves the formation of $\mathrm{LiOH}$ has also been raised recently although the mechanism is still not yet clear $^{36}$.

\section{$\underline{L i}_{2} \underline{O}_{2}$ oxidation to $\mathrm{O}_{2}$ on charge}

Electrochemical oxidation of $\mathrm{Li}_{2} \mathrm{O}_{2}$ does not require a true electrocatalyst - as does oxidation of $\mathrm{LiOH}$ in non-aqueous media, for example - because the $\mathrm{O}-\mathrm{O}$ bond is not cleaved on reduction. Oxidation of thin $\mathrm{Li}_{2} \mathrm{O}_{2}$-films on the electrode surface may be relatively facile whereas oxidation of large particles of insulating $\mathrm{Li}_{2} \mathrm{O}_{2}$ is a challenge (see next sections). Theoretical studies intriguingly suggested that the peroxide surface exhibits a half-metallic state ${ }^{37}$, but experimental proof of surface conductivity is lacking to date.

Many $\mathrm{Li}_{2} \mathrm{O}_{2}$ oxidation mechanisms have been invoked to provide a description of galvanostatic charge potential profiles. Elucidating the mechanistic origin of the charge profile is complicated by its dependence on two factors: (1) the discharge $\mathrm{Li}_{2} \mathrm{O}_{2}$ deposition mechanism, and hence the $\mathrm{Li}_{2} \mathrm{O}_{2}$ morphology, and (2) formation of products from parasitic reactions involving the cathode and
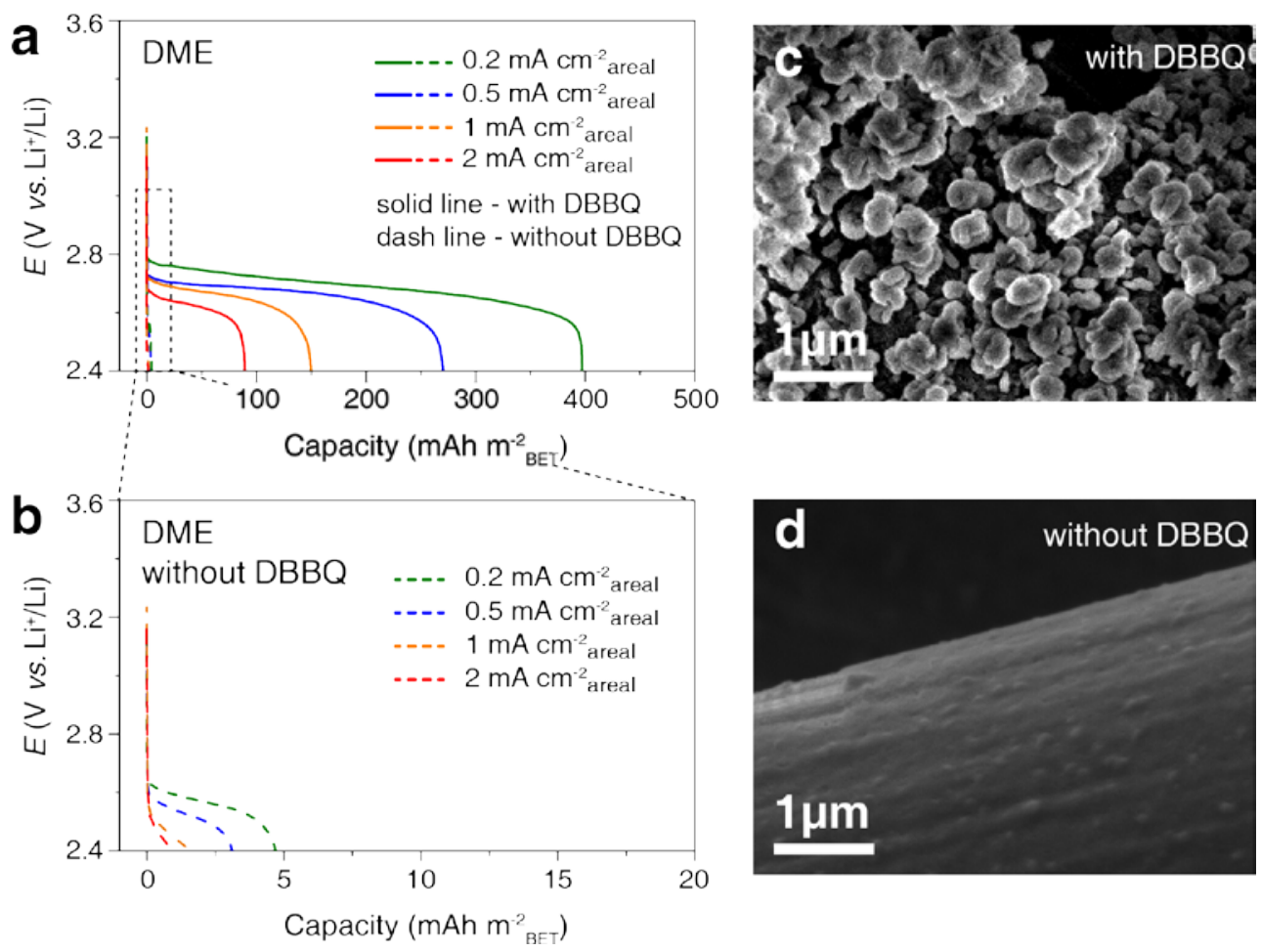

Figure 4 | Significant effect of DBBQ on discharge in ethers. Load curves for discharge of a $\mathrm{Li}_{-} \mathrm{O}_{2}$ cell $(\mathbf{a}, \mathbf{b})$; electrolyte solution LiTFSI in DME, at a gas diffusion electrode. By adding $10 \mathrm{mM} \mathrm{DBBQ}$ to the solution the capacity is increased 80 fold as the discharge mechanism changes from electrode surface (c) to solution growth of $\mathrm{Li}_{2} \mathrm{O}_{2}(\mathbf{d})$. Figure reproduced from Ref. 27. 
electrolyte during discharge and charge. These variables are intrinsically linked to the cell composition (i.e., the cathode and electrolyte employed), and numerous questions about the influence of these complexities on the mechanism and charge overpotential still remain to be answered. In theory, low overpotentials $\left(<0.2 \mathrm{~V}\right.$ ) exist for $\mathrm{O}_{2}$ evolution from $\mathrm{Li}_{2} \mathrm{O}_{2}$ at many $\mathrm{Li}_{2} \mathrm{O}_{2}$ crystal facets, as calculated using density functional theory ${ }^{38}$. This is in agreement with observations of $\mathrm{O}_{2}$ evolution at low $(\sim 3 \vee \mathrm{vs}$. $\mathrm{Li}^{+} / \mathrm{Li}$ ) potentials at early stages of charge from conformally deposited $\mathrm{Li}_{2} \mathrm{O}_{2}$. The ever increasing overpotential observed in these cells was proposed to be related to the deposition of solid carbonates at the $\mathrm{Li}_{2} \mathrm{O}_{2}$-electrolyte interface ${ }^{39,40}$ (see below).

Studies on charging electrodes pre-loaded with crystalline lithium peroxide have helped disentangle the oxidation of $\mathrm{Li}_{2} \mathrm{O}_{2}$ from side-reactions occurring on reduction related to $\mathrm{Li}_{2} \mathrm{O}_{2}$-induced decomposition of both the cathode and electrolyte. Such reactions deposit products on the peroxide that exhibit very high oxidation potentials, and thus inhibit $\mathrm{Li}_{2} \mathrm{O}_{2}$ oxidation to $\mathrm{O}_{2}{ }^{24,41}$. First, the studies demonstrate that the surface chemistry of the cathode support is critical in determining the efficiency of electron transfer to the insulating $\mathrm{Li}_{2} \mathrm{O}_{2}{ }^{42}$. Studies using preloaded cathodes have also elucidated the role of passivating films formed on surfaces such as nitrides and carbides which can either shut down or facilitate charging, as further discussed below. Second, micron sized crystalline peroxide particles exhibit a rather low charge overpotential (only $\sim 600 \mathrm{mV}$ for passivated metallic TiC cathode surfaces); much lower than one might expect. This is in agreement with the above finding - namely that lithium peroxide can be rather readily oxidized if decomposition products can be avoided to insure facile transport across interfaces.

Various mechanisms have been proposed for oxidation of $\mathrm{Li}_{2} \mathrm{O}_{2}$ deposited as toroids or incorporated into the cathode as a macroscopic particle-containing powder. Ganapathy et al. used operando X-ray diffraction (XRD) to show that a $\mathrm{Li}$ deficient component (i.e., $\mathrm{Li}_{2-\mathrm{X}} \mathrm{O}_{2}$ ) is formed during the charging process, presumably as a result of a one electron $\mathrm{Li}^{+}$de-insertion ${ }^{43}$. In fact, this mechanism was first proposed by theoretical studies which showed that topotactic delithiation based on $\mathrm{Li}_{2-\mathrm{x}} \mathrm{O}_{2}$ is rendered accessible at relatively small overpotentials of $0.3-0.4 \mathrm{~V}^{44}$. $\mathrm{Li}_{2} \mathrm{O}_{2}$ formed electrochemically via the solution mechanism described above often crystallizes in flat platelets, as determined from X-ray broadening, and as also observed by imaging ${ }^{45}$. In reference 43 , these are embedded in an amorphous lithium-bearing component (Fig. 5a), which may be comprised of both $\mathrm{Li}_{2} \mathrm{O}_{2}$ and side products arising from electrolyte degradation, such as formate, that can be oxidized at relatively low potentials without a catalyst ${ }^{41}$. Such products, formed on discharge, probably account for the less than $100 \%$ yield of peroxide (with respect to electrons passed in the cell) as determined by detailed assay studies ${ }^{46}$. The non-crystalline phase is removed first (Fig. $\mathbf{5 a} \rightarrow \mathbf{5 b}$ ) and at higher potentials, the underlying crystalline peroxide is proposed to charge via the Li-deficient solid solution $\left(\mathrm{Li}_{2-\mathrm{x}} \mathrm{O}_{2}\right)$ phase. The small actively oxidizing fraction results in a gradual reduction of the $\mathrm{Li}_{2} \mathrm{O}_{2}$ crystallites until their complete disappearance (Fig. $\mathbf{5 d}$ ). Although the mechanism of oxygen release is not yet clear, it is probable that Li-deficient $\mathrm{Li}_{2-\mathrm{x}} \mathrm{O}_{2}$ exists at the surface of $\mathrm{Li}_{2} \mathrm{O}_{2}$ in the cathode and immediately undergoes disproportionation as it forms to evolve $\mathrm{O}_{2}$. 
a

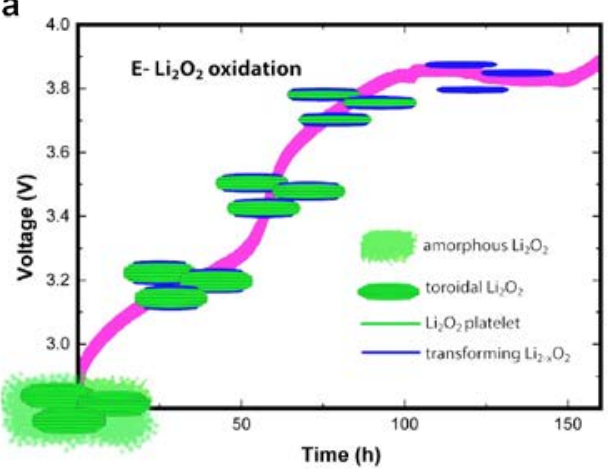

C

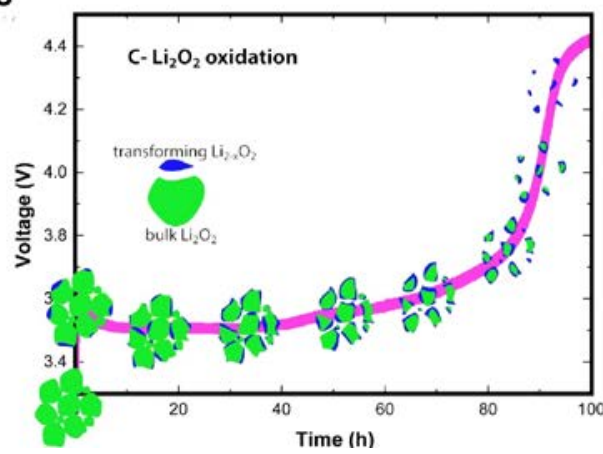

b
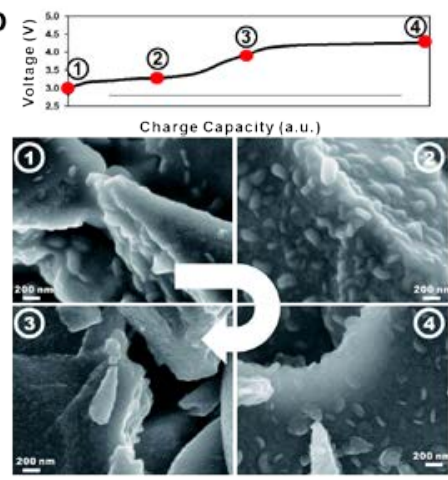

$\mathrm{d}_{\geq}$
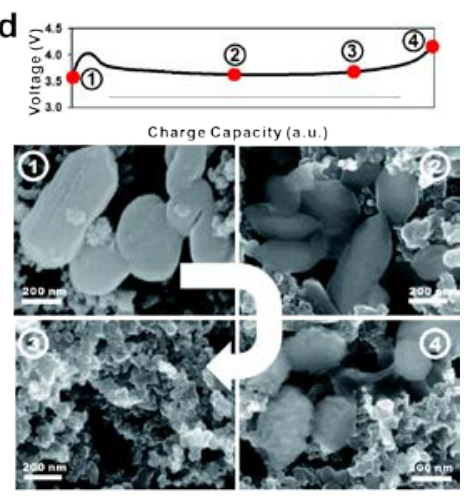

Figure 5 | Schematic showing the mechanism of $\mathrm{Li}_{2} \mathrm{O}_{2}$ oxidation during the charge. (a) Electrochemical E- $\mathrm{Li}_{2} \mathrm{O}_{2}$ and (c) crystalline $\mathrm{C}-\mathrm{Li}_{2} \mathrm{O}_{2}$. Scanning electron microscopy images (SEM) recorded at different stages of oxidation of $\mathrm{E}-\mathrm{Li}_{2} \mathrm{O}_{2}$ and $\mathrm{C}-\mathrm{Li}_{2} \mathrm{O}_{2}(1-4)$ are depicted in panels (b) and (d) respectively which show the electrochemical profiles. The white arrows indicate increasing state of charge. Figure reproduced from Ref. 43 American Chemical Society.

We note that some studies have suggested that the initial charging regime at low potentials is due to oxidation of a $\mathrm{LiO}_{2} / \mathrm{Li}_{2} \mathrm{O}_{2}$ type material formed on discharge based on observation of paramagnetic superoxide domains based on Raman and magnetic measurements ${ }^{47}$. While Li-deficient species are undoubtedly present at the peroxide surface, the Raman signature of the superoxide species is very close to that of the product formed by decomposition of the binder (PVdF) ${ }^{48}$ which has been well established to occur ${ }^{49}$, thus complicating the assignment. In fact, importantly, the signature peak does not appear when using Teflon as a binder in the cathode ${ }^{48}$. Further work is needed to resolve this open question.

\section{Soluble oxidation mediators for improved charging efficiency}

Although solution growth of $\mathrm{Li}_{2} \mathrm{O}_{2}$ is advantageous on discharge, as described above, it makes the charging of $\mathrm{Li}_{-} \mathrm{O}_{2}$ cells more challenging, because of the need to oxidize relatively large $\mathrm{Li}_{2} \mathrm{O}_{2}$ particles in the pores of the cathode somewhat remote from the electrode surface. Oxidation mediators can address this problem. They are molecules dissolved in the electrolyte that are oxidized at a potential slightly above the equilibrium potential of $\mathrm{Li}_{2} \mathrm{O}_{2}$ formation. Once oxidized at the electrode surface they diffuse to and oxidize $\mathrm{Li}_{2} \mathrm{O}_{2}$ particles. The substantially reduced charging overpotential is evident in the presence of an oxidation mediator is shown in Fig. 1c. Important properties include a high diffusion coefficient, fast charge transfer kinetics (particularly the charge transfer associated with $\mathrm{Li}_{2} \mathrm{O}_{2}$ oxidation) at voltages approaching the $\mathrm{Li}_{2} \mathrm{O}_{2}$ formation potential, and high stability. Many redox mediators have been proposed and explored ${ }^{50}$. Substantial interest in oxidation mediators was spurred by Chen et al.'s report of tetrathiafulvalene as an efficient mediator ${ }^{51}$. While the oxidation potential of TTF is higher than desired, recent reports have demonstrated other oxidation mediators with potentials closer to that for $\mathrm{Li}_{2} \mathrm{O}_{2}$ oxidation, including tris[4-(diethyl amino)phenyl]amine ${ }^{52}$, 
$\mathrm{TEMPO}^{53,54}, \mathrm{Lil}^{55,56,57}$, and a variety of quinone analogs and other redox-active molecules ${ }^{5859}$, that lower charge overpotentials without severely compromising electrolyte stability. Nevertheless, the search for a perfectly stable mediator with an appropriate operating voltage is still an important challenge. We note that the mediator approach requires the Li anode to be protected by a solid electrolyte membrane to avoid reaction of any mediator that diffuses to the anode.

\section{Li- $\mathrm{O}_{2}$ battery electrolytes}

Perhaps the largest scientific challenge facing $\mathrm{Li}_{-} \mathrm{O}_{2}$ batteries is long-term stability of the electrolyte. $\mathrm{Li}-\mathrm{O}_{2}$ cell configurations employ a liquid electrolyte comprised of a $\mathrm{Li}$ salt dissolved in an aprotic organic solvent. These electrolytes encounter highly reactive conditions. There are a plethora of critical reactions that the highly reactive reduced oxygen species (RROS) [e.g., $\mathrm{O}_{2} \cdot \mathrm{O}_{2}{ }^{2-}$, $\mathrm{HOO}$ and $\mathrm{HO} \cdot$ ] can undergo with various polar aprotic solvents. Over the past half-century in-depth studies have been carried out on the reactivity of these reduced oxygen species in general, and superoxide in particular, towards a wide-range of organic substrates ${ }^{60,61}$. While Li cations are highly electrophilic, in aprotic media, superoxide can function as a supernucleophile (equs. 8 and 9), as an efficient base (equ. 10), and as a good electron-transfer agent (equ. 11).

$$
\begin{aligned}
& \mathrm{RX}+\mathrm{O}_{2} \cdot-\mathrm{X}^{-}+\mathrm{ROO} \\
& \mathrm{RCOX}+\mathrm{O}_{2}{ }^{-} \rightarrow \rightarrow \mathrm{RCOO}^{-}+\mathrm{XO}^{-} \\
& \mathrm{RCH}_{2} \mathrm{CH}_{2} \mathrm{X}+\mathrm{O}_{2} \rightarrow \mathrm{RCH}=\mathrm{CH}_{2}+\mathrm{HO}_{2}^{-} \\
& \mathrm{A}+\mathrm{O}_{2} \rightarrow \mathrm{A}^{-}+\mathrm{O}_{2}
\end{aligned}
$$

Polar aprotic solvents (e.g., propylene carbonate, DMSO, DMA, DMF), all contain heteroatoms and, hence, polarized bonds. These polar solvents can undergo thermodynamically favourable reactions with RROS in the presence of $\mathrm{Li}$ ions ${ }^{60}$. A good example are alkyl carbonates which undergo nucleophilic attack that is effected either by the electrochemically formed superoxide anion radicals $\left(\mathrm{O}_{2}-;\right.$; equ 9$)$ or by the peroxide dianion $\left[\mathrm{O}_{2}{ }^{2-}\right]^{62,63,64}$. Polyethers such as glymes are not highly polar. Hence they are generally more inert solvents, although they too can undergo limited attack on $\alpha-\mathrm{H}$ and $\beta-\mathrm{H}$ (different possible locations in the polyether molecules for nucleophilic attack) by superoxide and peroxide species formed by oxygen reduction ${ }^{65,66,67,68,49}$ (equ. 12\&13).

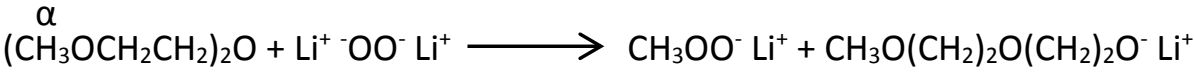

$$
\begin{aligned}
& \left(\mathrm{CH}_{3} \mathrm{OCH}_{2} \mathrm{CH}_{2}\right)_{2} \mathrm{O}+\mathrm{Li}^{+} \mathrm{OO}^{-} \mathrm{Li}^{+} \longrightarrow \mathrm{CH}_{3} \mathrm{O}^{-} \mathrm{Li}^{+}+\mathrm{CH}_{3} \mathrm{O}\left(\mathrm{CH}_{2}\right)_{2} \mathrm{O}\left(\mathrm{CH}_{2}\right)_{2} \mathrm{OO}^{-} \mathrm{Li}^{+}
\end{aligned}
$$

Reactivity is attributable to two factors. One is that not only the superoxide, but also the peroxide, is considered a super-nucleophile owing to the adjacent pairs of non-bonding electrons. ${ }^{69}$ The actual nucleophilicity is much higher than would have been expected based on its basicity. The second factor is the omnipresence of the highly electrophilic lithium cations. The latter bond strongly to the lone pairs of the oxygen atoms of the ether molecules which are hard Lewis bases. This promotes conversion of the alkoxy groups of polyethers into much better leaving groups, facilitating their loss upon nucleophilic attack. 
Despite their relatively inactive nature, glyme molecules can be also attacked by $\mathrm{O}_{2}-$ or $_{2} \mathrm{O}^{2-}$ moieties, which act as bases. While peroxide and superoxide species are not necessarily strong bases (e.g. the $\mathrm{pK}_{\mathrm{a}}$ of $\mathrm{HOO}$ is 4.7), the presence of $\mathrm{Li}^{+}$ions - which are strong Lewis acids - in solutions may facilitate concerted elimination reactions of glymes. The Li ions interact with the oxygen atoms of the ethers thus enabling formation of $\mathrm{Li}$-alkoxide leaving groups (e.g. $\mathrm{CH}_{3} \mathrm{OLi}$ ) simultaneous with proton abstraction by superoxide or peroxide moieties.

Another important possible route of reactions may relate to the radical nature of superoxide moieties. While the superoxide anion radical is a "super" nucleophile, and it is not considered a strongly active radical moiety, evidence of its (or the hydroperoxy radical) deleterious effect exists. ${ }^{70}$

Finally, it was also suggested that superoxide can induce the oxidation of various substrates via initial hydrogen atom abstraction ${ }^{71}$. However, thermochemical calculations and experimental data may suggest that superoxide is not a strong enough oxidizer. Any oxidation process observed during ORR may result from base-catalysed autoxidation (rather than from oxidation by superoxide). This suggestion certainly warrants further study. Consequently, it can be concluded that the partial instability of polyether solvents during oxygen reduction in the presence of Li ions stems from a combination of nucleophilic substitution and elimination reactions as major possible side reactions ${ }^{38}$.

In previous work, $\mathrm{Li}_{2} \mathrm{O}_{2}$ was found to be reactive with glymes as it was electrochemically formed, and prolonged exposure of $\mathrm{Li}_{2} \mathrm{O}_{2}$ at low currents resulted in lower $\mathrm{Li}_{2} \mathrm{O}_{2}$ yields during discharge. ${ }^{46}$ Based on extensive work and observation, the side reactions of these solvents in $\mathrm{Li}_{2} \mathrm{O}_{2}$ cells are most pronounced and fast when the oxygen reduction products are present in the solution phase, before final precipitation ${ }^{71}$. To overcome the instability of the ethereal solutions, Nazar et al. protected the ethylene oxide backbone of dimethoxyethane (DME) by methylation. ${ }^{72}$ These analogues demonstrated better cyclability of $\mathrm{Li}_{-} \mathrm{O}_{2}$ cells and less accumulation of side products compared to unprotected DME.

DMSO based electrolyte solutions and carbon free electrodes such as $\mathrm{Au}^{73}$, and $\mathrm{TiC}^{74}$ have demonstrated impressive cycling behaviour. However, as with all solvents studied so far, DMSO reacts with superoxide radicals ${ }^{75}$, and also peroxide ${ }^{76,77}$ to generate the dimsyl anion and a hydroperoxy radical nucleophile ${ }^{78}$. The latter can attack the sulfur atom of the sulfoxide moiety, yielding the corresponding dimethyl sulfone $\left(\left(\mathrm{CH}_{3}\right)_{2} \mathrm{SO}_{2}\right)$ and lithium hydroxide. DMSO also reacts with lithium metal, and thus lightly protected anodes and/or a combination of the above-mentioned reactivity may underlie variability in reported results for this electrolyte solvent.

Given the particularly aggressive nature of RROS species towards organic molecules, exploration of purely inorganic electrolytes may be an interesting direction of research. To this end, solid inorganic ceramics have been employed to serve as both a $\mathrm{Li}_{-} \mathrm{O}_{2}$ electrolyte and an oxygen and waterimpermeable Li metal protective layer ${ }^{34,79,80,81,82}$. Engineering a low-impedance porous cathodeelectrolyte interface with long-term stability will be a critical challenge facing this cell architecture. Recently, an intermediate temperature $\left(\sim 150{ }^{\circ} \mathrm{C}\right)$ molten salt electrolyte, based on the $\mathrm{LiNO}_{3}-\mathrm{KNO}_{3}$ eutectic, was also found to be stable in the presence of the $\mathrm{Li}^{-\mathrm{O}_{2}}$ cathode electrochemistry ${ }^{83}$. Identifying lower temperature inorganic molten salt alternatives and cathodes with improved stability (discussed in a later section) are useful directions to explore when employing these electrolytes.

In summary, it appears that all "commercial" off the shelf electrolytes examined to date exhibit instability to superoxide/peroxide moieties formed during oxygen reduction, in the presence of Li ions. Some modifications, e.g., using fluorinated solvents may enhance stability but severely reduces Li salt solubility. Hence, a compromise must be found, which could arise from designer electrolytes. 


\section{Designing better cathodes'}

Many important properties have to be considered when designing a practical Li-air battery cathode. $\mathrm{Li}_{2} \mathrm{O}_{2}$ is an electronic insulator, insoluble (or very sparingly soluble) in all known organic liquid-based electrolytes, and a strong oxidizer. As a result, a cathode has to be designed to provide sufficient electronic conductivity and $\mathrm{Li}^{+} / \mathrm{O}_{2}$ transport, be resilient towards $\mathrm{Li}_{2} \mathrm{O}_{2}$-induced oxidation, and not promote parasitic processes associated with the electrolyte and $\mathrm{Li}_{2} \mathrm{O}_{2}$ (Fig. 6). Typical $\mathrm{Li}_{-} \mathrm{O}_{2}$ battery cathodes usually comprise a mixture of high surface area carbon/catalyst powders bound to a porous current collector using a polymer binder. A large number of materials have now been studied for each of these cathode components, and general guidelines for material development are still emerging. This section will highlight useful cathode material properties and the effect of cathode composition on the performance of a Li-air battery.

Heterogeneous Catalysis at the Cathode. Substantial effort in the Li-air field has been devoted to identifying heterogeneous electrocatalysts to reduce overpotentials of both the oxygen reduction (discharge) and, in particular, oxygen evolution (charge) reactions. However, given the problematic stability issues observed with the electrolyte and cathode carbon, careful quantitative analysis of product formation must always be performed to confirm any claims of true $\mathrm{Li}_{2} \mathrm{O}_{2}$ formation/oxidation electrocatalytic performance ${ }^{84}$. In fact, when such quantitative measures are taken, parasitic electrolyte decomposition has been observed as the primary reaction being catalysed when using efficient aqueous ORR electrocatalysts ${ }^{85}$. For example, the best known ORR catalyst, Pt, was observed to most efficiently catalyse these parasitic reactions, allowing electrolyte oxidation to occur at potentials $(<3.5 \mathrm{~V})$ that, by themselves, would lead to erroneous conclusions about efficient $\mathrm{Li}_{2} \mathrm{O}_{2}$ oxidation ${ }^{85}$. Additionally, in cases where $\mathrm{Li}_{2} \mathrm{O}_{2}$ forms as a film on the electrode surface, the presence of a heterogeneous electrocatalyst on the electrode would be of little value beyond the first monolayer. It has been shown by Viswanathan et al., that electrochemical formation and oxidation of $\mathrm{Li}_{2} \mathrm{O}_{2}$ films is actually quite facile on glassy carbon surfaces, with constructed Tafel plots for this redox reaction being similar to what would be expected of a fast, reversible reaction with an exchange

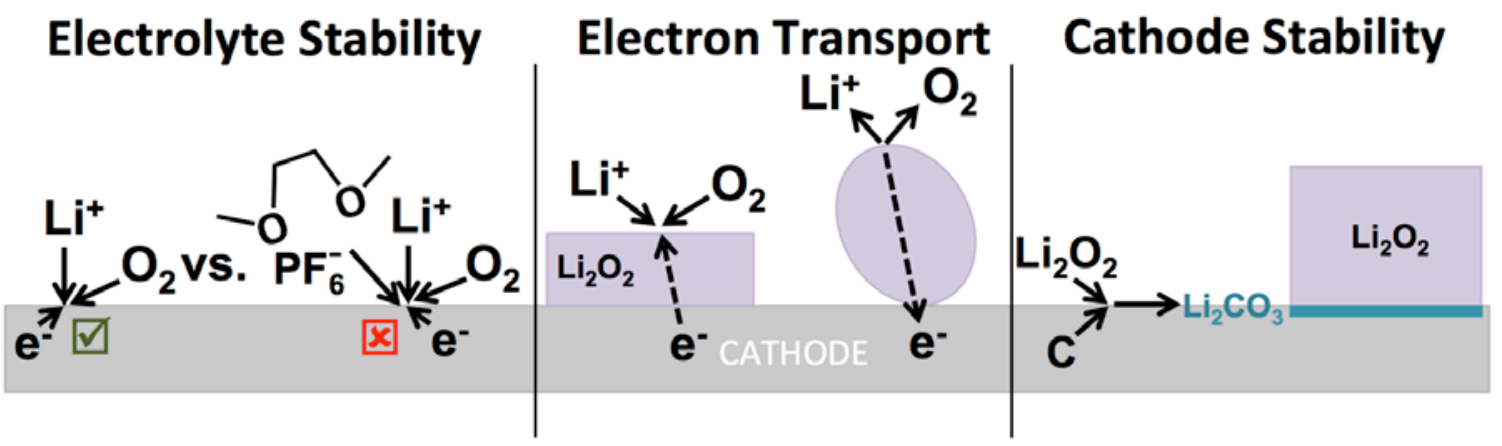

Figure 6 | Challenges facing the $\mathrm{Li}_{-} \mathrm{O}_{2}$ battery cathode. The three largest challenges are the suppression of electrocatalytic activity towards electrolyte degradation, solutions to circumvent $\mathrm{Li}_{2} \mathrm{O}_{2}$-induced electrode passivation, and stability of cathode materials at high voltages and in the presence of $\mathrm{Li}_{2} \mathrm{O}_{2}$. The electrolyte stability image depicts the ideal case of $\mathrm{O}_{2}$ reacting solely with $\mathrm{Li}^{+}$and $\mathrm{e}^{-}$at the electrode surface, ultimately forming $\mathrm{Li}_{2} \mathrm{O}_{2}$, and the non-ideal, parasitic case of solvent (dimethoxyethane shown as an example) and anion (hexafluorophosphate shown) participation in the electrochemical reaction. The electron transport image depicts the electronic conductivity limitations through a conformal, insulating $\mathrm{Li}_{2} \mathrm{O}_{2}$ film, as may happen during discharge, and conductivity limitations through large $\mathrm{Li}_{2} \mathrm{O}_{2}$ toroids during the charging process $\left(\mathrm{Li}_{2} \mathrm{O}_{2}\right.$ film or toroid formation is controlled by electrolyte properties discussed previously). The cathode stability image depicts a potential parasitic reaction that can occur between $\mathrm{Li}_{2} \mathrm{O}_{2}$ and porous carbon, which is typically used as a cathode material. 
current density of $\sim 1 \mathrm{~mA} / \mathrm{cm}^{2}$ (Fig. 7a) ${ }^{86}$. In fact, Viswanathan et al. make a compelling argument that reducing overall cell impedance is substantially more important to eliminate overpotentials than improved ORR electrocatalysis.

On charge, the apparently large overpotential has been linked to deposition of solid electrolyte decomposition products at the $\mathrm{O}_{2}$ evolving surface, the $\mathrm{Li}_{2} \mathrm{O}_{2}$-electrolyte interface (Fig. $7 \mathbf{b}$ ), and not to poor $\mathrm{Li}_{2} \mathrm{O}_{2}$ oxidation kinetics ${ }^{39,86}$. As they are continuously formed, these carbonaceous products cover an increasingly larger portion of the $\mathrm{Li}_{2} \mathrm{O}_{2}$-electrolyte interface, therefore necessarily driving the charging potential to higher values over the course of the charging process. At the end of charge, the decomposition products oxidize at high $\left(>4.2 \mathrm{~V} \mathrm{vs} \mathrm{Li}^{+} / \mathrm{Li}\right)$ potentials. The identification of stable electrolytes that are not susceptible to oxidation, even with a carbon-only cathode, should result in improved energy efficiency. For example, the molten nitrate eutectic electrolyte mentioned previously exhibits high stability and measurable $\mathrm{Li}_{2} \mathrm{O}_{2}$ solubility, allowing $\mathrm{Li}_{2} \mathrm{O}_{2}$ to diffuse back to electronically accessible cathode surfaces ${ }^{83}$. As a result, extremely low overpotentials $(\sim 50 \mathrm{mV}$ at 0.25 $\mathrm{mA} / \mathrm{cm}^{2}$ ) throughout discharge and most of charge, with analytically confirmed $2 \mathrm{e}^{-}$ORR and OER, were observed when employing this electrolyte in a carbon cathode-based cell.

Cathode stability. Although carbon has many desirable characteristics (high electronic conductivity and surface area, cost effective) that make it widely used as a cathode material, it degrades during Li$\mathrm{O}_{2}$ battery operation. For example, ${ }^{13} \mathrm{CO}_{2}$ evolution was observed during charge from a $\mathrm{Li}-\mathrm{O}_{2}$ cell employing a cathode composed of high purity ${ }^{13} \mathrm{C}$ carbon black, indicating that a parasitic reaction between $\mathrm{Li}_{2} \mathrm{O}_{2}$ and $\mathrm{C}$ occurs during cell operation, particularly at oxidative potentials (Fig. $\left.\mathbf{7 b}\right)^{39,87}$. Thotiyl et al. and Itikis et al. observed that this $\mathrm{Li}_{2} \mathrm{O}_{2} / \mathrm{C}$ reaction is influenced by the carbon surface composition, with a more hydrophilic and defective carbon surface resulting in faster carbon degradation ${ }^{87,88}$.
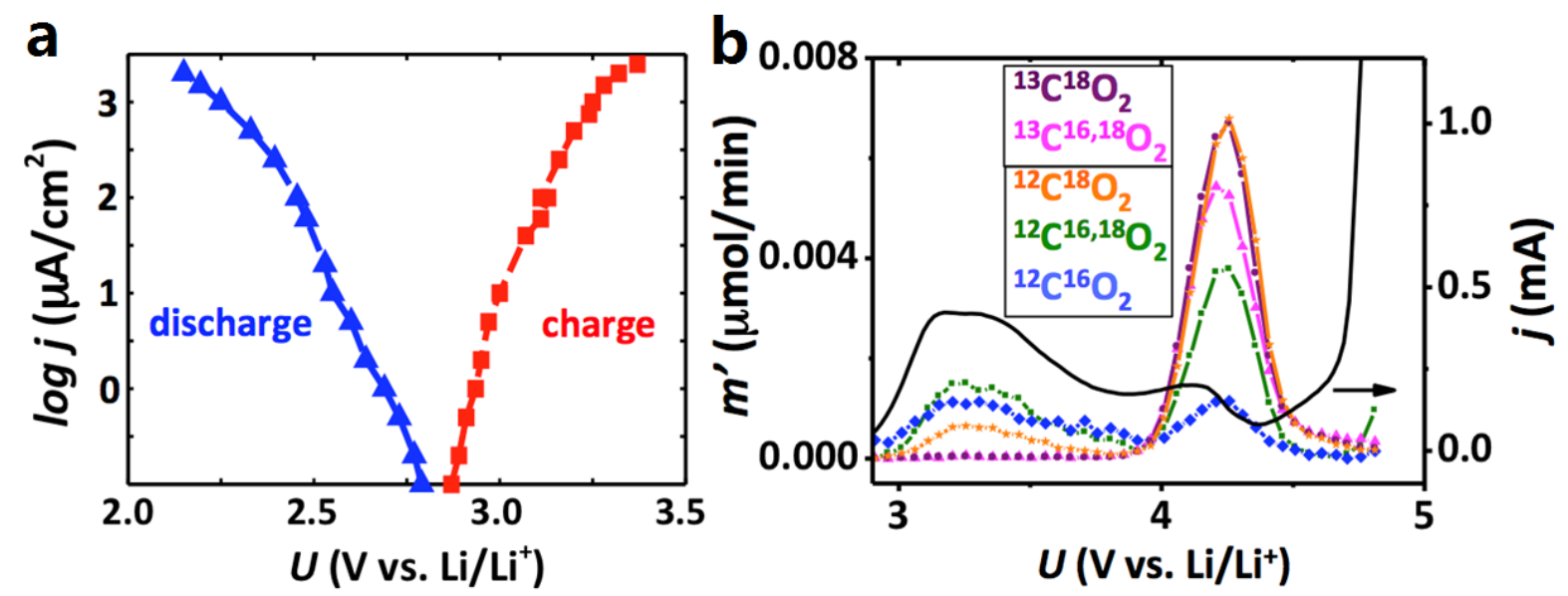

Figure 7 | Kinetics of $\mathrm{Li}_{2} \mathrm{O}_{2}$ formation and oxidation and origins of $\mathrm{CO}_{2}$ evolution. (a) Cathodic (discharge) and anodic (charge, after a short discharge) Tafel plots for $\mathrm{Li}^{-\mathrm{O}_{2}}$ electrochemistry at a flat, nonporous glassy carbon working electrode in a well-mixed bulk electrolysis cell (1 M LiTFSI in DME as the electrolyte). $j$ is the current density in $\mathrm{mA} / \mathrm{cm}^{2}$. (b) Linear sweep voltammogram $(0.5 \mathrm{mV} / \mathrm{s})$ and concomitant $\mathrm{CO}_{2}$ evolution from a $\mathrm{Li}-\mathrm{O}_{2}$ cell discharged $\left(\sim 1 \mathrm{mAh} / \mathrm{cm}^{2}\right)$ under ${ }^{18} \mathrm{O}_{2}$, employing a ${ }^{13} \mathrm{C}$ cathode and normal isotope abundance electrolyte (1 M LiTFSI in DME). $\mathrm{m}^{\prime}$ is the gas evolution rate in $\mathrm{mmol} / \mathrm{min} .{ }^{12} \mathrm{CO}_{2}$ is evolved at low potentials ( $<4 \mathrm{~V}$ ), and has been linked to a parasitic reaction that deposits alkyl carbonates at the $\mathrm{Li}_{2} \mathrm{O}_{2}$-electrolyte interface. A mix of ${ }^{12} \mathrm{CO}_{2}$ and ${ }^{13} \mathrm{CO}_{2}$ is evolved at high potentials when solid carbonate products from carbon and electrolyte decomposition are oxidized. $\mathrm{O}_{2}$ evolution was roughly $50 x$ higher than total $\mathrm{CO}_{2}$ evolution below $4 \mathrm{~V}$ and is not shown for clarity. Figures adapted with permission from Ref. 86 (panel a) and 39 (panel b). 
Although these latter studies hold hope that a resilient carbon cathode could eventually be engineered, the search for alternative stable materials is also underway. Au and TiC were initially identified to provide more stable cycling than carbon ${ }^{73,74}$. Theoretical work confirms that growth of $\mathrm{Li}_{2} \mathrm{O}_{2}$ on TiC occurs via a surface conduction mechanism. ${ }^{89}$ Metallic nitrides are fully oxidized by $\mathrm{Li}_{2} \mathrm{O}_{2}$ when an anodic current is applied, completely inhibiting further electron transfer ${ }^{42}$. However, thermodynamically more stable metallic carbides, such as $\mathrm{TiC}$, form a thin layer of conductive $\mathrm{TiO}_{2-x}$, which acts to passivate the surface and inhibit further oxidation ${ }^{42,74} \cdot \mathrm{Li}_{2} \mathrm{O}_{2}$ oxidation is facilitated with a greatly decreased overpotential. Not all carbides are so stable. $\mathrm{Mo}_{2} \mathrm{C}$ reacts to form a surface layer of $\mathrm{MoO}_{2}$ on discharge, which appears to result in a low charge overpotential ${ }^{90}$, but in fact forms soluble $\mathrm{Li}_{x} \mathrm{MoO}_{3}$ and leads to electrode degradation ${ }^{91}$. Thus practical cathode materials must be designed such that their surfaces inhibit excessive oxidation and/or are concealed by conductive oxide layers. ${ }^{92,93,94}$ Deposition of thin metal oxide coatings, such as $\mathrm{Al}_{2} \mathrm{O}_{3}$, has also been used as a strategy to protect carbon from degradation ${ }^{95}$. Furthermore, electrocatalytic activity towards electrolyte decomposition also has to be taken into consideration when designing a new electrode material (Fig. 6).

Also of note, the stability of certain polymer binders has been called into question, with poly(vinylidene fluoride), a typical binder used in Li-ion batteries, being identified by Black et al. as unstable during battery operation. ${ }^{49}$ Higher stability alternatives include polyethylene, poly(tetrafluoroethylene), and Nafion, as shown from studies on chemical stability of polymers in the presence of $\mathrm{Li}_{2} \mathrm{O}_{2}$ by Nasybulin et $a l^{96}$.

Cathode passivation limiting cell capacity. The primary advantage that Li-air batteries potentially have over current state-of-the-art Li-ion batteries is their high theoretical specific energy. Of course, to attain high energy densities, the electrochemical capacity of the cell should be very high, with the required minimum $\mathrm{Li}^{-} \mathrm{O}_{2}$ capacity ultimately being a function of the battery pack configuration and composition. The projected required capacities by Gallagher et al. and Christensen et al. (5-30 $\mathrm{mAh} / \mathrm{cm}^{2}$ ) are relatively large compared to most reported capacity values found in the literature $\mathrm{r}^{7,97}$.

Numerous potential causes have been conjectured for the observed poor capacity, all of which are related to processes occurring at the porous cathode (rather than the Li metal anode). These include pore clogging induced by solid $\mathrm{Li}_{2} \mathrm{O}_{2}$ deposition, $\mathrm{O}_{2}$ transport limitations, and charge transport limitations ${ }^{7}$. When the surface mechanism for $\mathrm{Li}_{2} \mathrm{O}_{2}$ formation is dominant, cell death has been clearly linked to a substantial increase in charge transfer resistance related to a growing conformal $\mathrm{Li}_{2} \mathrm{O}_{2}$ film ${ }^{13,14,9825}$. Charge transfer through the growing $\mathrm{Li}_{2} \mathrm{O}_{2}$ film was probed by Viswanathan et al. to show the direct influence of charge transfer resistance and cell death at a flat, nonporous electrode, where pore clogging was not a possible cause for cell death ${ }^{98}$. A clear correlation therefore exists between cell capacity and the total cathode surface area when $\mathrm{Li}_{2} \mathrm{O}_{2}$ film growth is observed, as was reported by Meini et $a l^{99}$. As was discussed earlier, the ideal cathode design in a cell with a dominant solution mechanism of $\mathrm{Li}_{2} \mathrm{O}_{2}$ is likely different, with low surface area and high porosity possibly required.

\section{Outlook}

There has been real progress in understanding the fundamental chemistry and electrochemistry underpinning the aprotic $\mathrm{Li}_{-} \mathrm{O}_{2}$ battery. Work on the mechanism of the reaction at the positive discharge

electrode, $2 \mathrm{Li}^{+}+2 \mathrm{e}^{-}+\mathrm{O}_{2} \rightleftharpoons \mathrm{Li}_{2} \mathrm{O}_{2}$ has shown that electrolyte solutions which charge

strongly solvate $\mathrm{Li}^{+}$result in $\mathrm{O}_{2}$ reduction to $\mathrm{Li}_{2} \mathrm{O}_{2}$ occurring in solution, whereas solutions that weakly solvate $\mathrm{Li}^{+}$result in $\mathrm{Li}_{2} \mathrm{O}_{2}$ films on the electrode surface. Much recent $\mathrm{Li}_{-} \mathrm{O}_{2}$ work has focused on etherbased electrolytes, because of their superior stability compared with alternatives (especially those with high donor numbers). We can now understand why the use of such low donor number ethers 
leads to $\mathrm{Li}_{2} \mathrm{O}_{2}$ surface films, passivating the electrode and resulting in low rates and early cell death, whereas the use of high donor number electrolyte solutions, dominated by $\mathrm{Li}_{2} \mathrm{O}_{2}$ growth in solution, can lead to relatively high rates and high capacities. Nevertheless, low donor number solvents are attractive because they are generally more stable, being less susceptible to nucleophilic attack by reduced oxygen species. Recent work has shown that the pathway by which $\mathrm{O}_{2}$ is reduced to form $\mathrm{Li}_{2} \mathrm{O}_{2}$ can be altered, such that the intermediate $\mathrm{LiO}_{2}$, reactive towards electrolyte solutions, can be avoided and $\mathrm{O}_{2}$ reduction to $\mathrm{Li}_{2} \mathrm{O}_{2}$ can take place in solution despite the use of low donor number ethers. As a result, $\mathrm{Li}-\mathrm{O}_{2}$ cells using ether based electrolyte solutions can deliver high rates and high capacities, avoiding early cell death. This is achieved using a solution soluble mediator, which also raises the discharge potential.

Understanding charge overpotentials after $\mathrm{Li}_{2} \mathrm{O}_{2}$ has been formed via the solution mechanism is an important direction of future research. Charge transport associated with toroids likely contributes to the overpotentials observed on charge, and hence the interest in developing stable oxidation redox mediators. However, other factors could also substantially contribute to the observed overpotential, such as electrolyte and cathode degradation. It is worth comparing the solution mechanism of $\mathrm{Li}_{2} \mathrm{O}_{2}$ formation to the chemistry of the $\mathrm{Na}-\mathrm{O}_{2}$ battery, where $\mathrm{NaO}_{2}$ rather than $\mathrm{Na}_{2} \mathrm{O}_{2}$ is the product, formed as large crystals tens of microns in size ${ }^{100} . \mathrm{NaO}_{2}$ is solubilized via a phase transfer catalyst that operates both on discharge and charge, leading to little hysteresis and a low overpotential on charging despite the large crystallite size ${ }^{101}$. Thus, to take advantage of $\mathrm{Li}_{2} \mathrm{O}_{2}$ growth, it is necessary to utilize soluble oxidation mediators to oxidize the insoluble $\mathrm{Li}_{2} \mathrm{O}_{2}$ particles on charging. In effect the reaction at the positive electrode becomes one in which $\mathrm{Li}_{2} \mathrm{O}_{2}$ acts as the energy storage medium, coupled electrochemically to the electrode surface via molecular mediators.

Work on the effect of $\mathrm{H}_{2} \mathrm{O}$ has shown that in contrast to earlier expectations, several 100s of ppm $\mathrm{H}_{2} \mathrm{O}$ can be tolerated with the overall reaction still being dominantly $\mathrm{Li}_{2} \mathrm{O}_{2}$ formation and oxidation However, there is evidence that $\mathrm{H}_{2} \mathrm{O}$ changes the reaction pathway. Importantly the proton activity of $\mathrm{H}_{2} \mathrm{O}$ in an aprotic organic solvent can be much less than in water, explaining in part why addition of significant quantities of $\mathrm{H}_{2} \mathrm{O}$ does not radically change the overall reaction (i.e., $\mathrm{Li}_{2} \mathrm{O}_{2}$ is still the dominant discharge product even in a water-contaminated cell).

Although advances in understanding the underlying mechanisms has opened up promising directions for $\mathrm{Li}_{-} \mathrm{O}_{2}$ cells exhibiting good rate and capacity with cycleability, challenges remain. In particular, in our opinion, these are the problems of electrode and electrolyte stability. Although there have been important advances in exploring cathode materials including modified carbons, breakthroughs are still required to demonstrate a low-cost, low mass, conductive, and highly stable porous gas diffusion cathode. A deeper understanding of the decomposition reactions occurring in the electrolyte solution is providing sound foundation of fundamental understanding that will define directions for the exploration of more stable electrolytes. It is important to place electrode and electrolyte stability in context. Most batteries are thermodynamically unstable and operate because of kinetic stability. Namely, there are always decomposition reactions, such as in the case of lead-acid batteries. It is not a question of whether the electrode or electrolyte is stable or unstable in $\mathrm{Li}_{-} \mathrm{O}_{2}$ but rather is the degree of instability sufficiently small to not decrease performance over the cycle and calendar life of the battery. The nature of the decomposition products are important. If these are benign and soluble they may not degrade performance, whereas if they are insulating and deposited on the electrode surface, they strongly limit cell lifetime. Comparing $\mathrm{Li}^{-} \mathrm{O}_{2}$ with other so called "beyond Li-ion" batteries, Li-S has been commercialized but not in a form that takes full advantage of its high specific energy. Rechargeable divalent metal batteries, $\mathrm{Mg}$, $\mathrm{Ca}$ and $\mathrm{Zn}$, still present formidable challenges. The jury is out on which, if any, beyond Li-ion batteries will make it to the market place. 
In conclusion, disruptive technologies do not happen overnight. Generally, years of effort and fundamental understanding and its exploitation in addressing challenges is required. In fields outside batteries this has been well illustrated and well understood. The recent example of the commercialization of organic light emitting diodes, which, some 20 years ago was identified as a potentially promising game changing technology, illustrates this reality. It is not yet known whether the problems that remain a challenge for the aprotic $\mathrm{Li}_{-} \mathrm{O}_{2}$ will ultimately be solved, but the last few years have identified many promising pathways forward to a solution.

\section{Acknowledgements}

PGB is indebted to the EPSRC, including the SUPREGEN program, for financial support. LFN gratefully acknowledges Natural Resources Canada, and also NSERC for funding through its Discovery and Research Chair programs. D.A. thanks Prof. Aryeh Frimer and Daniel Sharon, BIU for helpful discussions and the Israel Science Foundation (ISF) for support in the framework on the INREP project. BDM gratefully acknowledges financial support from the FY 2014 Vehicle Technologies Program Wide Funding Opportunity Announcement, under Award Number DE-FOA-0000991 (09911872), by the U.S. Department of Energy (DOE) and National Energy Technology Laboratory (NETL) on behalf of the Office of Energy Efficiency and Renewable Energy (EERE).

\section{References}

1 Imanishi, N., Luntz, A. C. \& Bruce, P. G. The Lithium Air Battery: Fundamentals. (Springer, 2014).

2 Lu, J.,Park, J.B., Sun, Y.-K., Wu, F., \& Amine, K. Aprotic and Aqueous Li-O 2 Batteries. Chem. Rev., 114, 5611-5640 (2014).

3 Abraham, K. M. Prospects and Limits of Energy Storage in Batteries. J. Phys. Chem. Lett. 6, 830-844, (2015).

4 Grande, L. et al. The Lithium/Air Battery: still an Emerging System or a Practical Reality? Adv Mater 27, 784-800, (2015).

5 Abraham, K. M. \& Jiang, Z. A polymer electrolyte-based rechargeable lithium/oxygen battery. J. Electrochem. Soc. 143, 1-5, (1996).

6 Ogasawara, T., Debart, A., Holzapfel, M., Novak, P. \& Bruce, P. G. Rechargeable $\mathrm{Li}_{2} \mathrm{O}_{2}$ electrode for lithium batteries. J. Am. Chem. Soc. 128, 1390-1393, (2006).

$7 \quad$ Christensen, J. et al. A critical review of Li/air batteries. J. Electrochem. Soc. 159, R1-R30 (2012).

8 Cheng, X.-B. et al. A Review of Solid Electrolyte Interphases on Lithium Metal Anode. Advanced Science 3, 1500213, (2016).

9 Bruce, P. G., Freunberger, S. A., Hardwick, L. J. \& Tarascon, J.-M. Li-O 2 and Li-S Batteries with High Energy Storage. Nature Mater. 11, 19-29 (2012).

10 Oleg, S., Vikram, P., Abhishek, K., Chayanit, C. \& Venkatasubramanian, V. Quantifying the Promise of 'Beyond' Li-Ion Batteries. Translational Materials Research 2, 045002 (2015).

11 Adams, B. D. et al. Current Density Dependence of Peroxide Formation in the $\mathrm{Li}-\mathrm{O}_{2}$ Battery and its Effect on Charge. Energy Env. Sci. 6, 1772-1778 (2013).

This paper and Ref. 12 showed that $\mathrm{Li}_{2} \mathrm{O}_{2}$ can form as either a surface film or particles depending on the current density.

12 Horstmann, B. et al. Rate-Dependent Morphology of $\mathrm{Li}_{2} \mathrm{O}_{2}$ Growth in $\mathrm{Li}_{-} \mathrm{O}_{2}$ Batteries. J. Phys. Chem. Lett., 4, 4217-4222 (2013).

13 Johnson, L. et al. The Role of $\mathrm{LiO}_{2}$ Solubility in $\mathrm{O}_{2}$ Reduction in Aprotic Solvents and its Consequences for Li-O2 Batteries. Nature Chem. 6, 1091-1099 (2014). 
This paper demonstrated that the solvation of the intermediate, $\mathrm{LiO}_{2}$, controls the mechanism of discharge.

14 Aetukuri, N. B. et al. Solvating Additives Drive Solution-Mediated Electrochemistry and Enhance Toroid Growth in Non-Aqueous Li-O 2 Batteries. Nature Chem. 7, 50-56 (2015).

15 Lim, H.-K. et al. Toward a Lithium-“Air” Battery: The Effect of $\mathrm{CO}_{2}$ on the Chemistry of a LithiumOxygen Cell. J. Am. Chem. Soc. 135, 9733-9742 (2013).

16 Kwabi, D. G. et al. Experimental and Computational Analysis of the Solvent-Dependent $\mathrm{O}_{2} / \mathrm{Li}^{+}-\mathrm{O}_{2}{ }^{-}$ Redox Couple: Standard Potentials, Coupling Strength, and Implications for Lithium-Oxygen Batteries. Angew. Chem. Int. Ed. 55, 3129-3134, (2016).

17 Gerbig, O., Merkle, R., Maier, J., Electron and Ion Transport in $\mathrm{Li}_{2} \mathrm{O}_{2}$. Adv. Mater., 25, 3129-3133 (2013).

18 Gutmann,V., Solvent Effects on Reactivity of Organometallic Compounds, Coord. Chem. Rev.,18, 225255, (1976)

19 Henderson, W. A. Glyme-Lithium Salt Phase Behavior, J. Phys. Chem. B, 2006, 110, 13177-13183, (2006)

20 Burke, C. M., Pande, V., Khetan, A., Viswanathan, V., \& McCloskey, B. D., Enhancing Electrochemical Intermediate Solvation Through Electrolyte Anion Selection to Increase Nonaqueous $\mathrm{Li}_{-} \mathrm{O}_{2}$ Battery Capacity. Proc. Natl. Acad. Sci. 112, 9293-9298 (2015).

This paper, along with Ref. 21,22 , demonstrated that the salt anion can promote a solution-based mechanism during discharge.

21 Sharon, D. et al. Mechanistic Role of $\mathrm{Li}^{+}$Dissociation Level in Aprotic Li-O 2 Battery. ACS Appl. Mater. Interfaces 8, 5300-5307 (2016).

22 Gunasekara, I., Mukerjee, S., Plichta, E. J., Hendrickson, M. A. \& Abraham, K. M. A Study of the Influence of Lithium Salt Anions on Oxygen Reduction Reactions in Li-Air Batteries. J. Electrochem. Soc. 162, A1055-A1066, (2015).

23 Schwenke, K. U., Metzger, M., Restle, T., Piana, M. \& Gasteiger, H. A. The Influence of Water and Protons on $\mathrm{Li}_{2} \mathrm{O}_{2}$ Crystal Growth in Aprotic $\mathrm{Li}_{2} \mathrm{O}_{2}$ Cells. J. Electrochem. Soc. 162, A573-A584, (2015).

24 Meini, S., Piana, M., Tsiouvaras, N., Garsuch, A. \& Gasteiger, H. A. The Effect of Water on the Discharge Capacity of a Non-Catalyzed Carbon Cathode for $\mathrm{Li}_{-} \mathrm{O}_{2}$ Batteries. Electrochemical and SolidState Letters 15, A45-A48, (2012).

This paper showed that water as an impurity has a significant effect on discharge capacity.

25 Luntz, A. C. et al. Tunneling and Polaron Charge Transport through $\mathrm{Li}_{2} \mathrm{O}_{2}$ in $\mathrm{Li}_{-}-\mathrm{O}_{2}$ Batteries. J. Phys. Chem. Lett. 4, 3494-3499, (2013).

26 Koper, M. T. M. Thermodynamic Theory of Multi-Electron Transfer Reactions: Implications for Electrocatalysis. J. Electroanal. Chem. 660, 254-260 (2011).

27 Gao, X., Chen, Y., Johnson, L. \& Bruce, P. G. Promoting Solution Phase Discharge in $\mathrm{Li}^{-\mathrm{O}_{2}}$ Batteries Containing Weakly Solvating Electrolyte Solutions. Nature Mater, in press. (2016) doi: 10.1038/nmat4629.

This paper demonstrated a homogeneous catalyst for $\mathrm{O}_{2}$ reduction that results in a dominant solution mechansm during discharge and large capacities.

28 Lacey, M. J., Frith, J. T. \& Owen, J. R. A Redox Shuttle to Facilitate Oxygen Reduction in the Lithium Air Battery. Electrochem. Commun. 26, 74-76 (2013).

29 Yang, L., Frith, J. T., Garcia-Araez, N. \& Owen, J. R. A New Method to Prevent Degradation of LithiumOxygen Batteries: Reduction of Superoxide by Viologen. Chem. Commun. 51, 1705-1708 (2015).

30 Sun, D. et al. A Solution-Phase Bifunctional Catalyst for Lithium-Oxygen Batteries. J. Am. Chem. Soc. 136, 8941-8946 (2014).

31 Andrews, L. Infrared Spectrum, Structure, Vibrational Potential Function, and Bonding in the Lithium Superoxide Molecule $\mathrm{LiO}_{2}$. J Chem Phys 50, 4288-4299, (1969). 
32 Bryantsev, V. S., Blanco, M. \& Faglioni, F. Stability of Lithium Superoxide $\mathrm{LiO}_{2}$ in the Gas Phase: Computational Study of Dimerization and Disproportionation Reactions. J. Phys. Chem. A 114, 81658169, (2010).

33 Lu, J. et al. A lithium-Oxygen Battery Based on Lithium Superoxide. Nature 529, 377-382, (2016).

34 Visco, S. et al. Aqueous and Nonaqueous Lithium-Air Batteries Enabled by Water-Stable Lithium Metal Electrodes. J. Solid State Electrochem., 18, 1443-1456 (2014).

35 Lee, J.-S. et al. Metal-Air Batteries with High Energy Density: Li-Air versus Zn-Air. Adv. Energy Mater. 1, 34-50, (2011).

36 Liu, T. et al. Cycling Li-O⿰冫 2 Batteries via LiOH Formation and Decomposition. Science 350, 530-533, (2015).

37 Radin, M.D., Rodriguez, J.F., Tian, F., Siegel, D. Lithium Peroxide Surfaces Are Metallic, While Lithium Oxide Surfaces Are Not. J. Am. Chem. Soc., 134, 1093-1103 (2012).

38 Hummelshøj, J. S., Luntz, A. C., \& J. K. Nørskov. J. Chem. Phys. 138, 034703 -034713 (2013).

This paper provided theoretical evidence for low overpotentials for $\mathrm{O}_{2}$ evolution from $\mathrm{Li}_{2} \mathrm{O}_{2}$ surfaces.

39 McCloskey, B. D. et al. Twin Problems of Interfacial Carbonate Formation in Nonaqueous $\mathrm{Li}_{-}-\mathrm{O}_{2}$ Batteries. J. Phys. Chem. Lett. 3, 997-1001 (2012).

This paper identified the major side reactions between the discharge products and cell components.

40 Mekonnen, Y. S., Garcia-Lastra, J. M., Hummelshøj, J. S., Jin, C. \& Vegge, T. Role of $\mathrm{Li}_{2} \mathrm{O}_{2} @ \mathrm{Li}_{2} \mathrm{CO}_{3}$ Interfaces on Charge Transport in Nonaqueous Li-Air Batteries. J. Phys. Chem. C 119, 18066-18073, (2015).

41 Oh, S. H., Adams, B., Lee, B. \& Nazar, L.F. A Direct, Soft Chemical Route to Mesoporous Metallic Lead Ruthenium Pyrochlore and Exploration of Its Electrochemical Properties, Chem. Mater, 27, 2322-2331 (2015).

42 Adams, B. D. et al. The Importance of Nanometric Passivating Films on Cathodes for Li-Air Batteries. ACS Nano 8, 12483-12493 (2014).

43 Ganapathy, S. et al. Nature of $\mathrm{Li}_{2} \mathrm{O}_{2}$ Oxidation in a $\mathrm{Li}_{-} \mathrm{O}_{2}$ Battery Revealed by Operando X-Ray Diffraction, J. Am. Chem. Soc., 136, 16335-16344 (2014).

44 Kang, S.Y., Mo, Y, Ong, S.P, \& Ceder, G., A Facile Mechanism for Recharging $\mathrm{Li}_{2} \mathrm{O}_{2}$ in $\mathrm{Li}^{-\mathrm{O}_{2}}$ Batteries. Chem. Mater., 25, 3328-3336 (2013).

45 Mitchell, R.R., Gallant, B.M., \& Shao-Horn, Y. Mechanisms of Morphological Evolution of $\mathrm{Li}_{2} \mathrm{O}_{2}$ Particles during Electrochemical Growth. J. Phys. Chem. Lett, 4, 1060-1064 (2013).

46 McCloskey, B. D. et al. Combining Accurate $\mathrm{O}_{2}$ and $\mathrm{Li}_{2} \mathrm{O}_{2}$ Assays to Separate Discharge and Charge stability Limitations in Nonaqueous Li-O2 Batteries. J. Phys. Chem. Lett. 4, 2989- 2993 (2013).

47 Yang, J., Zhai, et al. Evidence for Lithium Superoxide-Like Species in the Discharge Product of A Li-O $\mathrm{O}_{2}$ Battery. Phys. Chem. Chem. Phys. 15, 3764-3771 (2013).

48 Luntz, A.C., McCloskey, B.D. Nonaqueous Li-Air Batteries: A Status Report. Chem. Rev., 114, 1172111750 (2014).

49 Black, R. et al. Screening for Superoxide Reactivity in $\mathrm{Li}_{-} \mathrm{O}_{2}$ Batteries: Effect on $\mathrm{Li}_{2} \mathrm{O}_{2} / \mathrm{LiOH}$ Crystallization. J. Am. Chem. Soc. 134, 2902-2905 (2012).

This paper presents a study on the chemical reactivity of superoxide and Li2O2 with various cell components.

50 Chase, G.V. et al. Soluble Oxygen Evolving Catalysts for Rechargeable Metal-Air Batteries. US patent app. \#13/093,759: 2011.

This patent and Ref. 51 are the first studies to employ redox mediators in an attempt to suppress charge overpotentials. 
51 Chen, Y., Freunberger, S. A., Peng, Z., Fontaine, O. \& Bruce, P. G. Charging a Li-O⿰冫 2 Battery Using a Redox Mediator. Nature Chem. 5, 489 - 494 (2013).

52 Kundu, D., Black, R., Adams, B. \& Nazar, L.F. A Highly Active Low Voltage Redox Mediator for Enhanced Rechargeability of Lithium-Oxygen Batteries. ACS Central Science, 1, 510-515 (2015).

53 Bergner, B. J., Schürmann, A., Peppler, K., Garsuch, A. \& Janek, J. TEMPO: A Mobile Catalyst for Rechargeable Li-O 2 Batteries. J. Am. Chem. Soc. 136, 15054-15064 (2014).

54 Bergner, B. J. et al. Understanding the Fundamentals of Redox Mediators in $\mathrm{Li}_{-} \mathrm{O}_{2}$ Batteries: A Case Study on Nitroxides. Phys. Chem. Chem. Phys., 17, 31769-31779, (2015).

55 Kwak, W.-J. et al. Understanding the Behavior of Li-Oxygen Cells Containing Lil. J. Mater. Chem. A 3, 8855-8864 (2015).

56 Zhang, T., Liao, K., He, P. \& Zhou, H. A Self-Defense Redox Mediator for Efficient Lithium- $\mathrm{O}_{2}$ Batteries. Energy Environ. Sci. 9, 1024-1030 (2016).

57 Lim, H. D. et al. Superior Rechargeability and Efficiency of Lithium-Oxygen Batteries: Hierarchical Air Electrode Architecture Combined with A Soluble Catalyst. Angew. Chem. Int. Ed. 53, 3926-3931, (2014).

58 Feng, N., He, P. \& Zhou, H. Enabling Catalytic Oxidation of $\mathrm{Li}_{2} \mathrm{O}_{2}$ at the Liquid-Solid Interface: The Evolution of an Aprotic Li-O 2 Battery. ChemSusChem 8, 600-602, (2015).

59 Liu, J. et al. An Organic Catalyst for Li-O2 Batteries: Dilithium Quinone-1,4-Dicarboxylate. ChemSusChem 8, 2198-2203, (2015).

60 Frimer, A. A., Rosenthal, I., Chemical Reactions of Superoxide Anion Radical in Aprotic Solvents Photochem. Photobiol. 28, 711-717, (1978).

61 Sawyer, D. T., Valentine, J. S., How Super is Superoxide? Acc. Chem. Res. 14, 393-400 (1981).

62 Aurbach, D., Daroux, M., Faguy, P., Yeager, E., The Electrochemistry of Noble Metal Electrodes in Aprotic Organic Solvents Containing Lithium Salts. Journal of Electroanalytical Chemistry and Interfacial Electrochemistry 297, 225-244 (1991).

This paper, along with Refs. 63-68, elucidated instabilities of organic $\mathrm{Li}^{+}$electrolytes during oxygen reduction.

63 Freunberger, S.A. et al. Reactions in the Rechargeable Lithium- $\mathrm{O}_{2}$ Battery with Alkyl Carbonate Electrolytes. J. Am. Chem. Soc. 133, 8040-8047 (2011).

64 Mizuno, F., Nakanishi, S., Kotani, Y., Yokoishi, S., Iba, H., Rechargeable Li-Air Batteries with CarbonateBased Liquid Electrolytes. Electrochemistry 78, 403-405 (2010).

65 Freunberger, S.A. et al.., The Lithium-Oxygen Battery with Ether-Based Electrolytes. Angew. Chem., Int. Ed. 50, 8609-8613 (2011).

66 McCloskey, B. D., Bethune, D. S., Shelby, R. M., Girishkumar, G., Luntz, A. C., Solvents' Critical Role in Nonaqueous Lithium-Oxygen Battery Electrochemistry. J. Phys. Chem. Lett. 2, 1161-1166 (2011).

67 Assary, R.S., Lau, K.C., Amine, K., Sun, Y.-K. \& Curtiss, L. A. Interactions of Dimethoxy Ethane with Li2O2Clusters and Likely Decomposition Mechanisms for Li-O2Batteries. J. Phys. Chem. C 117, 80418049, (2013).

68 Sharon, D. et al. On the Challenge of Electrolyte Solutions for Li-Air batteries: Monitoring Oxygen Reduction and Related Reactions in Polyether Solutions by Spectroscopy and EQCM. J. Phys. Chem. Lett. 4, 127-131 (2013).

69 Younesi, R., Hahlin, M., Björefors, F., Johansson, P. \& Edström, K. Li-O 2 Battery Degradation by Lithium Peroxide ( $\left.\mathrm{Li}_{2} \mathrm{O}_{2}\right)$ : A Model Study. Chem. Mater. 25, 77-84, (2012).

70 Cao, R. et al. The Mechanisms of Oxygen Reduction and Evolution Reactions in Nonaqueous LithiumOxygen Batteries. ChemSusChem, 7, 2436-2440 (2014).

71 Khetan, A., Pitsch, H., Viswanathan, V., Solvent Degradation in Nonaqueous $\mathrm{Li}_{-} \mathrm{O}_{2}$ Batteries: Oxidative Stability versus H-Abstraction. J. Phys. Chem. Lett. 5, 2419-2424 (2014). 
72 Adams, B. D. et al. Towards A Stable Organic Electrolyte for the Lithium Oxygen Battery. Adv. Energy Mater. 5, 1400867 (2015).

A method of stabilising ethers is presented by replacement of the reactive protons with methyl groups.

73 Peng, Z., Freunberger, S. A., Chen, Y. \& Bruce, P. G. A Reversible and Higher-Rate Li-O ${ }_{2}$ Battery. Science 337, 563-566, (2012).

74 Ottakam Thotiyl, M. M. et al. A Stable Cathode for the Aprotic Li-O2 Battery. Nature Mater. 12, 10506 (2013).

75 Gibian, M. J., Ungermann, T., Reaction of Tert-butyl Hydroperoxide Anion with Dimethyl Sulfoxide. On the Pathway of the Superoxide-Alkyl Halide Reaction. J. Org. Chem. 41, 2500-2502 (1976).

76 Kwabi, D.G. et al. Chemical Instability of Dimethyl Sulfoxide in Lithium-Air Batteries. J. Phys. Chem. Lett, 5, 2850-2856 (2014).

77 Younesi, R., Norby, P. \& Vegge, T. A New Look at the Stability of Dimethyl Sulfoxide and Acetonitrile in $\mathrm{Li}_{-} \mathrm{O}_{2}$ Batteries. ECS Electrochemistry Letters 3, A15-A18, (2014).

78 Sharon, D. et al. Oxidation of Dimethyl Sulfoxide Solutions by Electrochemical Reduction of Oxygen. J. Phys. Chem. Lett. 4, 3115-3119 (2013).

79 He, P., Zhang, T., Jiang, J. \& Zhou, H. Lithium-Air Batteries with Hybrid Electrolytes. J. Phys. Chem. Lett. 7, 1267-1280, (2016).

80 Wang, Y., He, P. \& Zhou, H. A Lithium-Air Capacitor-Battery Based on A Hybrid Electrolyte. Energy Environ. Sci. 4, 4994-4999 (2011).

This paper showed a lithium-air capacitor-battery system based on a hybrid electrolyte.

81 Manthiram, A. \& Li, L. Hybrid and Aqueous Lithium-Air Batteries. Adv. Energy Mater. 5, 1401302, (2015).

82 Zhang, M. et al. Water-Stable Lithium Anode with $\mathrm{Li}_{1.4} \mathrm{Al}_{0.4} \mathrm{Ge}_{1.6}\left(\mathrm{PO}_{4}\right)_{3}-\mathrm{TiO}_{2}$ Sheet Prepared by Tape Casting Method for Lithium-Air Batteries. Journal of Power Sources 235, 117-121, (2013).

83 Giordani, V. et al. A Molten Salt Lithium-Oxygen Battery. J. Am. Chem. Soc. 138, 2656-2663 (2016).

This paper demonstrates a stable molten-salt electrolyte for $\mathrm{Li}_{-} \mathrm{O}_{2}$ batteries.

84 McCloskey, B. D., Burke, C. M., Nichols, J. E., Renfrew, S. E., Mechanistic Insights for the Development of $\mathrm{Li}-\mathrm{O}_{2}$ Battery Materials: Addressing $\mathrm{Li}_{2} \mathrm{O}_{2}$ Conductivity Limitations and Electrolyte and Cathode Instabilities. Chem. Commun. 51, 12701-12715 (2015).

85 McCloskey, B. D. et al. On the Efficacy of Electrocatalysis in Nonaqueous Li-O $\mathrm{O}_{2}$ Batteries. J. Am. Chem. Soc. 133, 18038-18041 (2011).

86 Viswanathan, V. et al. $\mathrm{Li}-\mathrm{O}_{2}$ Kinetic Overpotentials: Tafel Plots from Experiment and First-Principles Theory. J. Phys. Chem. Lett. 4, 556-560 (2013).

87 Ottakam Thotiyl, M. M., Freunberger, S. A., Peng, Z., Bruce, P. G., The Carbon Electrode in NonAqueous Li-O $\mathrm{O}_{2}$ Cells. J. Am. Chem. Soc. 135, 494-500 (2013).

88 Itkis, D. M. et al. Reactivity of Carbon in Lithium-Oxygen Battery Positive Electrodes. Nano Lett. 13, 4697-4701 (2013).

89 Wang, Z., Sun, J., Cheng, Y., \& Niu, C. Adsorption and Deposition of $\mathrm{Li}_{2} \mathrm{O}_{2}$ on TiC $\{111\}$ Surface. J. Phys. Chem. Lett. 5, 3919-3923 (2014).

90 Kwak, W.-J. et al. $\mathrm{A} \mathrm{MO}_{2} \mathrm{C} /$ carbon Nanotube Composite Cathode for Lithium-Oxygen Batteries with High Energy Efficiency and Long Cycle Life. ACS Nano, 9, 4129-4137 (2015).

91 Kundu, D. et al. Nanostructured Metal Carbides for Aprotic $\mathrm{Li}_{2} \mathrm{O}_{2}$ Batteries: New Insights into Interfacial Reactions and Cathode Stability. J. Phys. Chem. Lett., 6, 2252-2258 (2015). 
92 Kundu, D., Black, R., Berg, E. J., Nazar, L. F., A Highly Active Nanostructured Metallic Oxide Cathode for Aprotic Li-O 2 Batteries. Energy Environ. Sci. 8, 1292-1298 (2015).

93 Black, R., Lee, J.-H., Adams, B., Mims, C.A., \& Nazar, L.F. The Role of Catalysts and Peroxide Oxidation in Lithium-Oxygen Batteries. Angew. Chem. Int. Ed., 52, 392-396 (2013).

94 Cui, Y., Wen, Z., Liu, Y., A Free-Standing-Type Design for Cathodes of Rechargeable Li-O ${ }_{2}$ Batteries. Energy Environ. Sci. 4, 4727-4734 (2011).

95 Lu, J. et al. A Nanostructured Cathode Architecture for Low Charge oveRpotential in Lithium-Oxygen Batteries. Nature Comm. 4, 2383 (2013).

96 Nasybulin, E. et al. Stability of polymer binders in $\mathrm{Li}_{-} \mathrm{O}_{2}$ batteries. J. Power Sources 243, 899-907 (2013).

97 Gallagher, K. G. et al. Quantifying the Promise of Lithium-Air Batteries For Electric Vehicles. Energy Environ. Sci. 7, 1555-1563 (2014).

98 Viswanathan, V. et al. Electrical Conductivity in $\mathrm{Li}_{2} \mathrm{O}_{2}$ and Its Role in Determining Capacity Limitations in Non-Aqueous $\mathrm{Li}_{-} \mathrm{O}_{2}$ Batteries. J. Chem. Phys. 135, 214704 (2011).

This paper reported that $\mathrm{Li}_{2} \mathrm{O}_{2}$-induced cathode passivation limits $\mathrm{Li}^{-} \mathrm{O}_{2}$ battery capacity.

99 Meini, S., Piana, M., Beyer, H., Schwämmlein, J., \& Gasteiger, H. A., Effect of Carbon Surface Area on First Discharge Capacity of $\mathrm{Li}-\mathrm{O}_{2}$ Cathodes and Cycle-Life Behavior in Ether-Based Electrolytes. J. Electrochem. Soc. 159, A2135-A2142 (2012).

100 Hartmann, P. et al. A Rechargeable Room-Temperature Sodium Superoxide $\left(\mathrm{NaO}_{2}\right)$ battery. Nature Mater. 12, 228-232, (2013).

One of the first papers to demonstate a sodium $-\mathrm{O}_{2}$ battery that is able to cycle at a high current density.

101 Xia, C., Black, R., Fernandes, R., Adams, B. \& Nazar, L. F. The Critical roLe of Phase-Transfer Catalysis in Aprotic Sodium Oxygen Batteries. Nature Chem 7, 496-501, (2015).

This paper shows that protons catalyse a solution mechanism in sodium- $\mathrm{O}_{2}$ batteries. 